\title{
What can we learn on Chinese aid allocation motivations from available data? A sectorial analysis of Chinese aid to African countries.
}

\author{
Marlène Guillon ${ }^{1}$ and Jacky Mathonnat ${ }^{2}$
}

\begin{abstract}
:
Since the creation of the Forum on China-Africa Cooperation (FOCAC) in 2000, Chinese official development assistance (ODA) to Africa has increased drastically. Only a few analyses on the determinants of Chinese ODA allocation to African countries are available. Moreover, existing literature mainly focused on total aid flows while Chinese motivations for aid allocation might differ depending on the ODA sector considered. Our objective is to study the factors associated with Chinese aid allocation to African countries by sector between 2000 and 2014. We consider three ODA broad sectors as defined by the Organisation for Economic Cooperation and Development (OECD): the social infrastructure and services sector, the economic infrastructure and services sector and the production sector. Chinese ODA is measured using the AidData's Global Chinese Official Finance Dataset (Version 1.0), 2000-2014. Over the 2000-2014 period, China allocated 971, 218 and 138 ODA projects to African countries in the social infrastructure and services sector, the economic infrastructure and services sector and the production sector respectively. Between 2000 and 2014, the economic infrastructure and services sector was the first sector in terms of ODA amount with a total of US\$18.9 billion ahead from the social infrastructure and services sector with US\$7 billion or the production sector with US\$3.1 billion. Results of our analysis suggest that the motivations of Chinese aid allocation to African countries differ by sector. Chinese ODA in the social infrastructure and services sector appears more responsive to the economic needs of recipient countries but is also more driven by foreign policy considerations. Chinese economic interest, in particular for natural resources acquisition, is associated with China's ODA allocation in the economic infrastructure and services sector. Finally, while governance quality in recipient countries is not related to Chinese ODA in the social infrastructure and services sector, we find that China allocates more ODA in the economic infrastructure and services sector and the production sector to African countries with weaker institutions. One of the strong conclusions of this study is to show that considering only China's overall aid to Africa can be misleading as to its underlying determinants, and therefore to point out the need to disaggregate the analysis by ODA sectors.
\end{abstract}

Keywords: Official development assistance; China; Africa; sectorial analysis.

JEL Classification: F35

\footnotetext{
${ }^{1}$ Corresponding author. marlene.guillon@umontpellier.fr. Montpellier Recherche en Economie, Université de Montpellier. Avenue Raymond Dugrand, 34960 Montpellier Cedex 2. +33(0)4 34432491.

2 jacky.mathonnat@uca.fr. Université Clermont Auvergne, CNRS, CERDI and Senior Fellow, Head of the Health Economics Program, Fondation pour les Etudes et Recherches sur le Développement International (FERDI), 6365 boulevard François Mitterrand, 63000 Clermont-Ferrand. +33(0)4 73177403.
} 


\section{Introduction}

The Forum on China-Africa Cooperation (FOCAC) was created in 2000 in Beijing in order to strengthen Sino-African economic cooperation and diplomatic relationships. Since 2000, the volume of SinoAfrican trade has increased tremendously from US\$9.7 billion in 2000 to a peak of US\$215.9 billion in 2014 (United Nations Comtrade Database). Over the last 20 years, Chinese Foreign Direct Investments (FDI) in Africa have also risen drastically. The global Chinese FDI stock in Africa increased from US\$0.5 billion in 2003 to US\$21.7 billion in 2012 (United Nations Conference on Trade and Development Bilateral FDI Statistics). This stock reached US\$34.7 billion in 2015 (2015 Statistical Bulletin of China's Outward Foreign Direct Investment).

Since the creation of the FOCAC in 2000, Chinese official development assistance (ODA) to Africa has also largely increased. Between 2000 and 2014, African countries have received as much as 1592 Chinese ODA projects for a total amount of 34.8 billion of 2014US\$. In the political science literature, China is often accused of allocating its ODA in its own interests. China would allocate ODA to African countries mainly to guarantee its access to the natural resources of these countries and to secure export markets for its products. Moreover, Chinese ODA to Africa would also be used to extend China's international support (Naim, 2007, Lin et al., 2016). China refutes these accusations and states to allocate its ODA in response to the needs expressed by the recipient countries, following an equality and mutual benefit principle and according to a non-interference principle (Declaration of the Beijing Summit of the Forum on China-Africa Cooperation, 2006/11/05; Kjøllesdal et al., 2010; Second White Paper on China's Foreign Aid, 2014).

In addition to the literature on the determinants and impacts of Chinese FDI (Sanfilippo, 2010; Kolstad and Wiig, 2011; Kolstad and Wiig, 2012; Amighini et al., 2013; You and Solomon, 2015; Mourao, 2018), a recent literature on the determinants of Chinese ODA to African and non-African countries has emerged. As in the broader aid allocation literature on traditional donors, this recent literature has investigated the role of three types of variables that might influence Chinese aid allocation decisions: the needs and merits of recipient countries and the economic and political interests of China. Dreher and Fuchs (2015) study the determinants of Chinese aid allocation to all recipient countries over the 1956-2006 period. The authors use several data sources and focus on total Chinese aid as well as food aid and the number of Chinese medical teams sent to recipient countries. Their results point to the lack of influence of recipient countries' oil production for the receipt of total ODA projects and food aid but not for the receipt of Chinese medical teams. On the contrary, they show that the United Nations General Assembly (UNGA) voting alignment of recipient countries with China is positively correlated with all types of Chinese aid received except food aid. Results of Dreher and Fuchs (2015) also underline the prominence of political considerations in Chinese aid allocation. Broich (2017) studies the allocation of Chinese official development finance, comprising ODA and Other Official Flows (OOF), to African countries between 2000 and 2011. The author specifically focuses on whether authoritarian regimes receive more Chinese development finance than democratic ones. Using four different measures of democracy (the polyarchy index based on the Varieties of Democracy project, the Polity IV democracy index, the Freedom House democracy index and the Vanhanen's democratization index), and controlling for various confounding factors, such as Chinese economic and political interests or institutional quality in recipient countries, Broich (2017) finds that authoritarian countries do not systematically receive more Chinese official finance. In a very recent study, Dreher et al. (2018) focus on total amounts of Chinese ODA and Other Official Flows (OOF) to African countries 
over the 2000-2013 period. Their results confirm those of Dreher and Fuchs (2015). Indeed, they find that foreign policy considerations, as measured by Taiwan recognition, UNGA voting alignment or temporary membership of African countries on the United Nations Security Council, are significantly correlated with Chinese ODA amount and Chinese grants. On the contrary, they find that Chinese economic interests, as measured by recipient countries' trade with China or oil production, do not impact ODA allocation but only the allocation of less concessional flows (Other Official Flows - OOF). Guillon and Mathonnat (2017) study the factors associated with Chinese health ODA projects and amounts to African countries between 2006 and 2013. They find that Chinese health aid is responsive to the economic needs (as measured by the Gross Domestic Product - GDP - per capita) of recipient countries while it is unrelated to various measures of health needs or governance quality in African countries. They also find no strong evidence that Chinese health aid allocation decisions favour natural resource-rich countries or countries with important commercial ties with China. As highlighted by Dreher and Fuchs (2015) and Dreher et al. (2018) for Chinese ODA in all sectors, results of Guillon and Mathonnat (2017) confirm the idea that China uses its health aid as part of its foreign policy since nonadherence to the One-China policy makes the receipt of Chinese health aid very unlikely.

Existing literature on the determinants of Chinese aid allocation mainly focused on total aid flows or on specific types of aid such as food aid, health aid or the sending of medical teams. However, Chinese motivations for aid allocation might differ depending on the ODA sector considered. Three main types of aid sectors are defined by the OECD: the social infrastructure and services sector (thereafter referred to as the social sector), the economic infrastructure and services sector (thereafter referred to as the economic sector) and the production sector. Given the explicit economic interests of China in specific areas of African economies, such as the energy or the transportation sectors, one might hypothesize that economic motivations are more important in driving Chinese aid allocation in the economic and production sectors compared to the social sector. On the other hand, motivations behind aid allocation to the social sector might be more related to the needs of African countries given the lack of direct economic interests of China in this sector. Besides pure altruism, aid allocation in the social sector might also be used by China as a soft power to extend its international support and visibility.

Our objective is to study the factors associated with Chinese aid allocation to African countries over the 2000-2014 period. In particular, we aim to test whether variables related to the needs and merits of African countries and to the political and economic self-interest of China differently impact the volume of Chinese aid to African countries depending on the sector considered. Compared to the existing literature, this will refine our understanding of the factors influencing the allocation of Chinese aid to Africa. Given the lack of Chinese official ODA data, we measure Chinese aid allocation to Africa using the last version of the AidData's Global Chinese Official Finance Dataset (Version 1.0), 2000-2014 (Dreher et al., 2017). We focus on the number of Chinese ODA projects and on ODA amount. For ODA amount, the analysis is restricted to the economic broad sector given the very high shares of social and production projects that lack financial valorisation, $60.7 \%$ and $54.3 \%$ respectively.

Between 2000 and 2014, China allocated 971 ODA projects to African countries in the social sector. Over the same period, China financed 218 projects in the economic sector, amounting for a total of US\$18.9 billion, and 138 projects in the production sector. Our results suggest that factors associated with Chinese aid allocation depend on the sector considered. ODA in the social sector appears more responsive to the needs of African countries while it is also further linked to foreign policy considerations. Natural resources acquisition is associated with total Chinese ODA allocation and more 
specifically to ODA allocation in the economic and social sectors. Finally, in line with results found by the literature on the determinants of Chinese FDI, China tends to allocate more economic and production sector ODA to African countries with weaker political governance.

\section{Chinese ODA to African countries}

We use the last version of the AidData's Global Chinese Official Finance Dataset, 20002014, Version 1.0 to measure Chinese aid allocation to African countries. A complete description of the dataset and its methodology can be found in Strange et al. (2017) and Dreher et al. (2017).

In this database we selected Chinese ODA to African countries and gathered them in the three broad sectors defined by the OECD classification: the social sector, the economic sector and the production sector. The social sector gathers ODA in education, general and reproductive health, water supply and sanitation, government and civil society and other social infrastructures. The economic sector includes ODA in transport and storage, communications, energy, banking and business. Finally, the production sector comprises ODA in agriculture, forestry and fishing, industry, mining and construction, trade and tourism. Regarding the status of the projects, we chose to include only completed projects and projects currently under implementation. Committed or pledged projects for which the proof of money disbursement is lacking, as well as cancelled and suspended projects, were excluded from the analysis. Thus, we focus on Chinese aid disbursements, rather than commitments, to African countries.

Figure 1 shows the repartition of ODA projects and amount by broad sectors. A total of 1592 ODA projects were financed by China in Africa between 2000 and 2014 for a total amount of 34.8 (2014) US\$ billion. Over the 2000-2014 period, the social sector gathered 971 projects (61\% of all ODA projects) for a total amount of US\$7 billion (20.2\% of the total ODA amount). The economic sector grouped 218 projects ( $13.8 \%$ of total) with a total amount of US\$18.9 billion ( $54.4 \%$ of total). Finally, the production sector is the smallest broad sector as it included only 138 projects ( $8.7 \%$ of total) for a total amount of US\$3.1 billion (8.9\% of total). The main caveat for the analysis of Chinese ODA amount is the existence of missing values for the financial valorisation of ODA projects. This is particularly problematic in the social sector, where 557 ODA projects over 971 (60.7\%) lack financial valorisation, and in the production sector, where the financial amount is missing for 75 ODA projects over 138 (54.3\%). In the economic sector, only 63 ODA projects over 218 (28.9\%) lack financial valorisation. Smaller ODA amounts observed in the social and production sectors are then partly attributable to the higher shares of projects lacking financial valorisation in these two sectors. 
Repartiton of ODA projects by sector

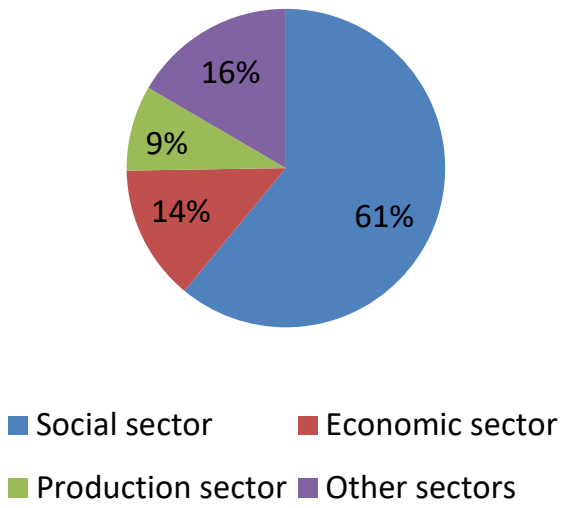

Repartiton of ODA amount by sector

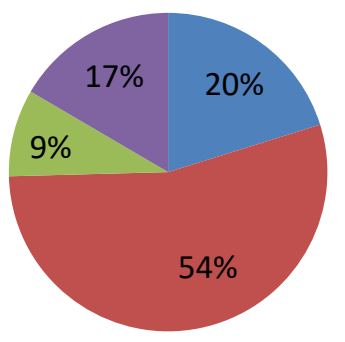

- Social sector Economic sector

- Production sector $\square$ Other sectors

Figure 1: Repartition of Chinese ODA projects and amount by sector

Table 1 shows the evolution of Chinese ODA projects and amount to African countries by broad sector between 2000 and 2014.

\begin{tabular}{|l|c|c|c|c|c|c|c|c|}
\cline { 2 - 10 } \multicolumn{1}{c|}{} & $\mathbf{2 0 0 0}$ & $\mathbf{2 0 0 1}$ & $\mathbf{2 0 0 2}$ & $\mathbf{2 0 0 3}$ & $\mathbf{2 0 0 4}$ & $\mathbf{2 0 0 5}$ & $\mathbf{2 0 0 6}$ & $\mathbf{2 0 0 7}$ \\
\hline Total projects & 36 & 34 & 44 & 66 & 77 & 59 & 115 & 117 \\
\hline Social projects & 27 & 23 & 33 & 49 & 44 & 38 & 78 & 89 \\
\hline Economic projects & 6 & 7 & 6 & 10 & 28 & 12 & 20 & 15 \\
\hline Production projects & 3 & 4 & 5 & 7 & 5 & 9 & 17 & 13 \\
\hline Total amount (2014 US\$ million) & 586 & 246 & 952 & 385 & 590 & 861 & 2480 & 1716 \\
\hline Social amount (2014 US\$ million) & 271 & 89 & 225 & 205 & 205 & 86 & 414 & 490 \\
\hline Economic amount (2014 US\$ million) & 258 & 93 & 713 & 145 & 384 & 761 & 1789 & 1095 \\
\hline Production amount (2014 US\$ million) & 57 & 64 & 14 & 35 & 0 & 14 & 278 & 131 \\
\hline & $\mathbf{2 0 0 8}$ & $\mathbf{2 0 0 9}$ & $\mathbf{2 0 1 0}$ & $\mathbf{2 0 1 1}$ & $\mathbf{2 0 1 2}$ & $\mathbf{2 0 1 3}$ & $\mathbf{2 0 1 4}$ & SD*/mean \\
\hline Total projects & 114 & 154 & 93 & 123 & 109 & 89 & 97 & 0.40 \\
\hline Social projects & 81 & 118 & 77 & 90 & 73 & 71 & 80 & 0.42 \\
\hline Economic projects & 12 & 14 & 10 & 22 & 29 & 13 & 14 & 0.50 \\
\hline Production projects & 21 & 22 & 6 & 11 & 7 & 5 & 3 & 0.69 \\
\hline Total amount (2014 US\$ million) & 1548 & 3234 & 1645 & 3890 & 6130 & 2507 & 2262 & 0.82 \\
\hline Social amount (2014 US\$ million) & 270 & 1785 & 808 & 424 & 1309 & 291 & 153 & 1.03 \\
\hline Economic amount (2014 US\$ million) & 1252 & 1349 & 838 & 3315 & 3508 & 1316 & 2109 & 0.83 \\
\hline Production amount (2014 US\$ million) & 26 & 100 & 0 & 151 & 1312 & 900 & 0 & 1.86 \\
\hline
\end{tabular}

Table 1: Evolution of ODA projects and amount by year and type of project

The number of projects in the economic and production sectors remained relatively stable over time. On the contrary, the number of ODA projects in the social sector increased over time, particularly between 2006 and 2009, and reached its peak in 2009 with 118 projects. Over the study period, ODA amounts appear more volatile than the number of ODA projects, especially in the economic sector. A first increase in the amount of economic ODA is observed in 2006 when it reached US\$1.8 billion. The amount of economic ODA then decreased steadily between 2006 and 2010. A new increase in the 
amount of economic ODA is then observed between 2010 and 2012. In 2012, the amount of economic ODA reached its peak at US\$3.5 billion. Beyond the global trends, it is therefore important to consider the instability of Chinese ODA. Coefficients of variation (standard deviation/average) show that instability is much stronger for economic and production projects than for total aid and for social sector support. If we look at the Herfindahl-Hirschman concentration index, we can also note that Chinese aid to Africa is not very concentrated for the number of projects in the three sectors, but that it is notably more for the amount, and quite strongly for production sector (see Table A1 in Appendix A).

\section{Hypotheses}

The literature on aid allocation has long investigated the impact of three main types of factors on the allocation decisions of donor countries: the needs and merits of recipient countries and the selfinterest of donors (Berthélemy and Tichit, 2004; Dollar and Levine, 2006; Berthélemy, 2006; Esser and Bench, 2011; Nunnenkamp and Öhler, 2011; Hoeffler and Outram, 2011; Lee and Lim, 2014). Following this literature, we investigate how these three factors influenced Chinese aid allocation to African countries over the 2000-2014 period. However, we do not consider global aid but rather investigate the differentiated effects of recipient needs, recipient merits and self-interest of China on the allocation of Chinese aid to African countries by broad sectors. Indeed, we assume that Chinese aid flows in the social, economic and production sectors follow different strategic ends. We formulate the following four hypotheses:

Hypothesis 1: aid in the social sector is more related to the needs of African countries compared to aid in the economic and production sectors.

Hypothesis 2: countries with lower governance quality should not receive less aid, whatever the sector, given the non-interference principle stated to be applied by China.

Hypothesis 3: Chinese economic interests are more important in driving aid allocation in the economic and production sectors compared to the social sector.

Hypothesis 4: aid allocation in the social sector is more influenced by Chinese political interests compared to aid in the economic and production sectors.

The social broad sector gathers aid in sectors linked to the development of the human resource potential, such as health or education, that are not directly related to the economic activity or production of recipient countries. On the other hand, the economic broad sector groups aid for sectors such as transport, energy, or communications, that are key to facilitate the economic activity in recipient countries while the production broad sector gathers all aid that aims to contribute directly to production sectors such as agriculture, industry, mining, construction or trade. The production and economic broad sectors therefore include sectors that are of specific economic interests for China given its commercial ties with African countries and its investment policy on the continent. Indeed, looking at the composition of Sino-African trade, most of Chinese imports from African countries relate to natural resources with fuels, minerals and metals making up respectively $38.5,14.8$ and $10.7 \%$ of Chinese imports from Africa in 2016 (World Integrated Trade Solution database). On the other hand, 
Chinese exports to African countries are dominated by the machinery and electrical sector $(26.9 \%$ of exports), the textiles and clothing sector (19.1\%), the metals sector (11.2\%) and the transportation sector (7.3\%). Turning to the composition of Chinese FDI in Africa, extraction and electricity accounted for almost half $(46 \%)$ of the Chinese FDI stock in Africa in 2015 with US\$30.1 billion invested ${ }^{3}$. Moreover, in 2015, infrastructure-related activities (electricity, construction and information and communications technology \& internet infrastructure) accounted for $13 \%$ of all Chinese FDI projects in Africa and for $44 \%$ of capital invested.

China frequently uses hybrid forms of financing arrangement; including grants, concessional loans, buyer credits and supplier credits - China EximBank and China Development Bank playing key roles and foreign direct investments; in its relations with developing countries (Kimura et Todo, 2010; Dollar, 2016; Carter, 2017). In addition, China uses export credits much more widely than other donors in the architecture of its aid flows to developing countries (Saidi and Wolf, 2011). Economic and production sectors offer more opportunities for the use of hybrid forms of aid financing than social sector interventions (Bräutigam, 2010). Thus, aid in these sectors might more often be tied or related to nonconcessional trade or investment flows. All these elements suggest that the economic incentives for China to allocate aid to the economic or production sectors are more important than they are for the social sector. We then hypothesize that economic interests' variables are likely to play a role in aid allocated to economic and production sectors, but play no role, or only a marginal one, in the volume of social aid allocated to African countries. Therefore, in the empirical analysis we expect to find a correlation between Chinese economic interests and the aid provided to recipient countries in the economic and production sectors, but no correlation between economic interests' variables and the volume of Chinese aid in the social sector. However, positive correlations could still be found between the economic interests' variables and Chinese aid allocation in the social sector if China uses its social aid as a form of "reward" or incentive for the opening of the African economies with China through trade and FDI. In such cases, these correlations should be of much lower magnitude than those observed for the economic or the production sectors.

By contrast, altruistic aid motives should be more prevalent in the social sector where economic returns of ODA are lower than in the economic or production sectors. If this hypothesis is confirmed, we should observe a positive correlation between the needs of African countries and the aid volume they receive from China in the social sector and no, or much lower correlations, between needs variables ${ }^{4}$ and the volume of aid in the economic and production sectors. Besides pure altruism, aid allocation in the social sector might also be further related to Chinese political interests compared to aid in the economic or production sectors. Several reasons could explain why aid in the social sector would more often be used as a form of soft power by China to extend its international support and visibility than the case for its aid to economic and production sectors. There is a large consensus among scholars to consider China's aid to be an important tool of foreign policy, part of the "Going out

\footnotetext{
${ }^{3}$ FDI Intelligence. The Africa investment report 2016.

Available at: https://www.camara.es/sites/default/files/publicaciones/the-africa-investment-report-2016.pdf.

${ }^{4}$ Of course this does not mean that Chinese aid in the economic and production sectors does not impact human welfare and development of recipient countries. As Dollar (2016) points out, "Infrastructure issues have clear connections to human welfare and economic development: improved water and sanitation support positive health outcomes and cognitive development; access to electricity is necessary both in the home (for reading and studying) and, of course, in industry and commerce" (op. cit. p. 51).
} 
strategy" (Going Global) policy endorsed by the government since the beginning of the 2000's. But the nature and the features of its involvement in economic and production sectors have been highly criticized by some Western countries, international organizations and many non-governmental organisations (Grimm, 2014, Wang, 2016; Carter, 2017). This is reinforced by "sections of African populations disagreeing with the image of China as a non-meddling altruistic partner which causes troubles for a country that attributes 'paramount importance' to its image" (Grimm, 2014, p. 17). China is then making considerable efforts to develop its soft power and to improve its overall image (Xue, 2014; Shambaugh, 2015). For the reasons quoted above, and since the leading role of the Chinese Ministry of Commerce in aid implementation has led to broad suspicions regarding the true China's motivations for its aid commitments in the economic and production sectors (Liao et al., 2018), the social sector appears as a good candidate for China to deploy its "soft" power foreign policy. Moreover, social ODA projects more often correspond to technical assistance (such as the sending of medical teams) or training programs (such as the allocation of grants for African students to study in Chinese universities or the creation of Confucius Institutes in African countries) that involve collaborations and cultural exchanges between China and Africa. Aid in the social sector therefore appears more appropriate to create bounds with African countries.

So far, we formulated general hypotheses on the differentiated impacts of needs, merits and selfinterest on Chinese aid allocation by sector. We now describe which instrument will be used to measure needs, merits and self-interest in order to formulate more precise hypotheses based on the four main hypotheses described above.

To measure the needs of African countries we use the logged GDP per capita and the ratio of the total debt service to Gross National Income (GNI). In a robustness analysis, we use the Human Development Index (HDI) instead of the GDP per capita as an alternative measure of African countries' needs. To measure the merits of recipient countries we use the control of corruption index of Kaufmann et al. (2011). This index is rated on a scale from -2.5 to 2.5 where a score of 2.5 represents the highest level of corruption control. We test for the impact of another measure of corruption: The Corruption Perceptions Index (CPI, Transparency International). As alternative measures of needs, we also use two other Worldwide Governance Indicators, namely the regulatory quality and rule of law index (Kaufmann et al., 2011). We distinguish between economic and political interests of China. To measure Chinese economic interests, we use two variables: the natural resources rent in African countries and their openness rate to China, both being measured as percentages of GDP. Political interests of China are taken into account by the use of two variables: The United Nations General Assembly (UNGA) voting alignment of African countries with China (Strezhnev and Voeten, 2013) and a binary variable which is equal to 1 if the country has official diplomatic relations with Taiwan (Rich, 2009). As a control variable we also insert a binary variable equal to 1 if English is an official language in the recipient country. In order to test whether Chinese ODA is a complement or a substitute to ODA of traditional donors, we also insert logged ODA commitments of Development Assistance Committee (DAC) countries (OECD data) as an explanatory variable. Table B1 in Appendix B provides the definitions and data sources of all explanatory variables.

Table 2 describes the expected signs for each independent variable. If GDP per capita is a good proxy to measure the needs of African countries, we expect to find a negative correlation between the GDP per capita and aid in the social sector but no correlation with aid in the economic or production sectors. The debt to GNI ratio might have several effects on the allocation of Chinese aid. If the debt to GNI is 
a proxy for the needs of African countries, i.e. if it represents the (in)ability of African countries to invest through public resources in social, economic and production sectors, we expect to find positive correlations between the debt to GNI ratio and Chinese aid allocation. On the other hand, given the large use of export credits and concessional loans in the architecture of Chinese aid flows, China might be reluctant to allocate aid to highly indebted countries, especially in the economic and production sectors where loans are more prevalent. The impact of the population level on the volume of aid is $a$ priori undetermined. Indeed, the literature on aid allocation has long shown the existence of a bias against highly-populated countries for the allocation of aid per capita (Cashel-Cordo and Craig, 1997; Berthélemy and Tichit, 2004; Dollar and Levin, 2006; Younas, 2008). However, as we are studying absolute aid volumes rather than aid per capita, the population level could represent a proxy for either the needs of African countries, or their economic weight, and therefore be positively correlated with the volume of Chinese aid received in the social, economic and production sectors.

\begin{tabular}{|c|c|c|}
\hline \multirow[t]{2}{*}{ Indicators } & \multicolumn{2}{|c|}{ Expected signs } \\
\hline & Social sectors & $\begin{array}{c}\text { Economic/production } \\
\text { sectors }\end{array}$ \\
\hline GDP per capita (logged) & - & n.e \\
\hline Debt to GNI ratio & $-/+$ & $-/+$ \\
\hline Population (logged) & $?$ & $?$ \\
\hline Control of corruption index & n.e & n.e \\
\hline Natural resources rent & $+/$ n.e & + \\
\hline Openness rate & $+/$ n.e & + \\
\hline UNGA voting alignment with China & + & + \\
\hline Taiwan recognition & - & - \\
\hline English-speaking country & + & + \\
\hline Social ODA DAC countries & ? & n.a \\
\hline Economic ODA DAC countries & n.a & ? \\
\hline Production ODA DAC countries & n.a & ? \\
\hline $\begin{array}{l}+/ \text { - positive } / \text { negative effect } \\
?=\text { Undetermined a priori effect on aid } \\
\text { n.e = no effect expected } \\
\text { n.a = not applicable }\end{array}$ & & \\
\hline
\end{tabular}

Table 2: Expected signs of explanatory variables by sector

Given the non-interference principle stated to be applied by China in its aid allocation, we expect to find no impact of governance quality in African countries on Chinese aid flows in either sector. For the openness rate to China and the natural resources rent, we expect to find positive correlations with aid flows in the economic and production sectors and no correlation, or much lower correlations, in the social sector. Indeed, as explained above, economic incentives for China to allocate aid to the economic or production sectors are more important than they are in the social sector. Adherence to the OneChina policy has been described as a necessary condition to benefit from Chinese aid (Bräutigam, 2009; Rotberg, 2009; Zhang and Smith, 2017). Therefore, we expect to find a negative correlation between 
Taiwan recognition and the receipt of Chinese aid in all sectors. For the UNGA voting alignment variable, we expect to find a positive correlation with aid received in the social sector and no correlation, or correlations of lower magnitude and significance, with aid in the economic or production sectors. Indeed, if aid in the economic and production sectors is already used by China to promote its economic interests, aid in the social sector remains the best aid instrument that can be used by China to seek political support and improve its image. We expect to find a positive correlation between the dummy for the English-speaking country and the receipt of Chinese aid in all sectors. Indeed, as mentioned by Dreher et al. (2018), the construction of the AidData dataset is heavily based on Chinese- and English-language sources which could lead to an underrepresentation of aid flows toward countries where other languages are more often used in "in media outlets, business relations, and politics". As part of its "Going Global" policy, China might choose to allocate more aid to countries that are already large recipients from DAC countries in order to diminish traditional donors' influence in these countries. On the contrary, China might choose to concentrate its aid on countries that are low aid recipients from DAC countries in order to secure political influence/alliances in countries that are not yet under a strong influence of traditional donors. Then, we do not make any a priori assumption on the correlations between DAC countries and Chinese sectorial aid flows.

\section{Methods}

\subsection{Dependent variables}

We study the number of ODA projects and the amount of ODA allocated by China to the different African countries. We stratify the analysis by broad ODA sectors and distinguish between ODA in the social, economic and production sectors. As financial valorisation is lacking for more than half of social (60.7\%) and production (54.3\%) ODA projects, we restrict the analysis of ODA amount to the economic sector. To derive the value of Chinese ODA in the economic broad sector we first calculate ODA amounts by country-year for each of the five individual sectors included in the broad economic sector (transport and storage, communications, energy generation and supply, banking and financial services and business and other services). For each individual sector, the amount of Chinese ODA is equal to 0 if a country received no Chinese ODA project in a given year while it is coded as missing if financial valorisation lacks for all projects received by a country in this sector a given year. If data on the financial amount is available for at least one project in the individual sector, the amount of ODA is calculated as the sum of all monetary values available for projects received by the country in a given year in this sector. After calculating ODA amounts in individual sectors, we derive the amount of economic ODA by summing the individual sectors' ODA amounts. For each country-year observation, the amount of economic ODA is equal to 0 if ODA amounts are null in all individual sectors. The amount of Chinese ODA in the economic broad sector is coded as missing if ODA amounts are null in all individual sectors. The amount of Chinese ODA in the economic broad sector is coded as missing if ODA amounts are lacking for all individual sectors. Otherwise, the value of Chinese economic ODA is calculated as the sum of all non-missing individual sectors' amounts. The overall correlation between economic ODA projects and amount is equal to 0.52 and is significant at the $1 \%$ level $\left.\right|^{5}$.

\footnotetext{
${ }^{5}$ Corresponding correlations are much lower for the social and production sectors, 0.2577 and 0.1992 respectively, due to a high share of missing values for the amount of ODA projects in these sectors.
} 


\subsection{Model specification}

A common practice in the aid allocation literature is to study the factors associated with the logtransformed volume of aid (Dollar and Levin, 2006; Fielding, 2011; Nunnenkamp and Öhler, 2011; Lee and Lim, 2014; Acht et al., 2015). In the context of aid allocation, the log-transformation of the dependent variable poses one problem related to the existence of 0 values when no aid is received. For 0 values, an ad-hoc nonlinear transformation, such as modelling $\ln (a i d+1)$, is needed to ensure that these observations do not drop out of the analysis. This arbitrary transformation is problematic if the share of 0 values is high in the sample under consideration. This is the case in our analysis since an important proportion of countries received no Chinese ODA project or amount each year. We then choose not to log-transform our dependent variables.

The overrepresentation of 0 values in our data needs to be dealt with when considering the model specification. In the context of aid allocation decisions, McGillivray (2003) has shown that a misleading regression line will almost always be fitted by Ordinary Least Squares (OLS) if observations for which the aid variable is equal to 0 are included in the sample. McGillivray (2003) illustrates this flaw by using a scenario where the volume of aid to a country $i$ is a decreasing function of an independent variable $X$. Because observations for which the aid volume is 0 are lying to the right of all other observations, the use of OLS tends to provide a regression line that is too flat. This implies that the regression coefficient of the independent variable $X$ is underestimated. In our study, the use of OLS regressions would therefore lead to underestimate the impact of needs, merits and interests' variables on Chinese ODA allocation. Thus, we need to use specific econometric models that account for the overrepresentation of 0 in our sample.

In the literature on the determinants of aid allocation, the overrepresentation of 0 values is often dealt with specific econometric models such as two-part models (Clist, 2011; Fink and Redaelli, 2011) or Heckman selection models (Neumayer, 2003; Berthelémy, 2006). However, the use of such models would assume that China proceeds sequentially in its aid allocation decisions by first choosing the recipient countries and then deciding on the volume of ODA to allocate to them. This assumption appears unrealistic since the literature has shown the lack of centralization and coordination in Chinese aid policy which involves multiple actors at the national and regional levels (Grépin et al., 2014; Lin et al., 2016). A third solution commonly implemented in the aid allocation literature to deal with 0 values is the use Tobit models (Berthelémy and Tichit, 2004; Dollar and Levin, 2006; Nunnenkamp and Öhler, 2011). Tobit models estimate the factors associated with the volume of aid in one step while correcting for the downward bias introduced by the many 0 observations.

In this paper, we use maximum-likelihood Poisson regression as our main specification and Tobit regression analysis as a check for robustness. Silva and Tenreyro (2006 and 2011) have demonstrated that Poisson models perform better than OLS or Tobit models in the presence of heteroscedasticity and many zero observations. This method is robust to different patterns of heteroscedasticity while its performance is not affected by the presence of a large proportion of 0 values for the dependent variable. Following the publications of Silva and Tenreyro (2006 and 2011), Poisson regressions have gained popularity in the trade literature for the estimation of gravity models. Poisson regressions are now considered as a natural way to deal with 0 values in trade or investment data as evidenced by the increasing number of articles using this method (Shepherd, 2010; Fernandes et al., 2016; Anderson and Yotov, 2016; Didier, 2016; Luo et al., 2017). Given similar econometric issues faced for the 
estimation of trade, investment or ODA flows, the use of Poisson regressions appears appropriate to study the factors associated with Chinese ODA amounts. Moreover, Poisson regressions have been used recently to estimate the factors associated with DAC countries' absolute amount of aid (Acht et al., 2015). We also use Poisson regressions to estimate the factors associated with the number of Chinese ODA projects received. Indeed, the number of projects received is a typical case of count data for which the use of Poisson regressions is more efficient than linear models. Poisson regressions have, for example, recently been used to estimate the factors associated with the number of outward direct investment (ODI) projects of Chinese state-owned and private-owned firms (Amighini et al., 2013). The overrepresentation of 0 values in the number of Chinese ODA projects received generates overdispersion in the data. In that case, maximum likelihood Poisson regressions are still consistent but might produce deflated standard errors. In order to account for the over-dispersion in the number of Chinese ODA projects received, we use Poisson regressions with robust variance estimators (Cameron and Trivedi, 2005, p. 670).

A part of the aid literature chooses to use aid shares of recipient countries in total aid of the donor country, rather than absolute amounts of aid, as dependent variables (Neumayer, 2003; Clist, 2011; Acht et al., 2015). To test the robustness of results based on absolute volumes of Chinese aid, we also run regression analyses using the share of Chinese aid received as the dependent variable. These regressions are run using fractional probit models (Papke and Wooldridge, 1996). The share ODA projects received by a country in a given year is equal to the number of ODA projects received by this country this year divided by the total annual number of Chinese ODA projects to African countries. Similarly, the share of economic ODA amount received by a country in a given year is equal to the amount of economic ODA received by the country this year divided by the annual total amount of Chinese economic ODA to African countries.

Fixed effects regressions only rely on intra-country heterogeneity over time for the estimation of regressions coefficients. The use of fixed effects regressions would be problematic in our analysis given the low within-country variability of some independent variables, such as Taiwan recognition or the governance quality indicators. Random effects models control for recipient-specific characteristics while allowing to estimate the coefficients of variables that exhibit little variation over time. However, the use of random effects Poisson regressions imposes strong hypotheses. First, individual effects need to be distributed independently of the regressors to obtain consistent estimates. Moreover, the random effects Poisson estimator assumes that random effects are gamma-distributed. Cameron and Trivedi $(2005$, p. 804 ) have shown that pooled Poisson regressions can be used as an alternative to random effects Poisson regressions if cluster-robust standard errors are used to account for equidispersion and serial correlation of the dependent variable. Given large year-to-year variation in the number and amount of Chinese ODA projects allocated to African countries, we use pooled regressions with year fixed effects as previously done in the aid allocation literature by Dollar and Levin (2006), Younas (2008) and Nunnenkamp and Öhler (2011).

The last concern for our analysis is the issue of reverse causality. Some of our independent variables; for example, the GDP per capita, the debt to GNI ratio or the openness rate; might impact the volume of Chinese aid received and, at the same time, be affected by the flow of Chinese aid. Such a situation would create endogeneity and require an instrumentation of the endogenous independent variables using specific econometric techniques such as two-stage least squares (2SLS). The application of such techniques necessitates the availability of valid instruments. Otherwise, estimation results can be 
contaminated by the use of a weak instrument. Given our focus on a multiple set of independent variables, and the difficulty to find valid instruments, we follow a common pattern in the aid allocation literature and we lag all independent variables by one year (except ODA amount from DAC countries and the dummy variable for English speaking countries) in order to limit reverse causation concerns (Berthélemy and Tichit, 2004; Younas, 2008; Stubbs et al., 2016). This technique also allows accounting for the time lag with which information about recipient countries are made available to China (Younas, 2008).

All regressions are run with robust standard errors clustered at the country level. We are interested in the sectorial effects of needs, merits and interests' variables on Chinese ODA to African countries. Then, we formally test the differences in the coefficients of these variables between the social, economic and production sectors. To do so, we run seemingly unrelated Poisson estimations using the "suest" command in Stata ${ }^{\circledR}$. This procedure combines the estimation results, parameter estimates and associated (co)variance matrices of the different regressions and store them into one parameter vector and simultaneous (co)variance matrix (StataCorp, 2015). The differences in the independent variables' coefficients by sector can then be tested properly.

\section{Results}

\subsection{Descriptive statistics}

Table 3 provides the descriptive statistics of dependent and independent variables for the sample used in the main regression analyses. On average, African countries received 1.93 Chinese ODA projects per year in all broad sectors between 2000 and 2014. The maximum number of Chinese ODA projects received by an African country over a given year is 11 for Uganda in 2014. Over the 2000-2014 period, the mean annual number of social projects is 1.39 with a maximum of 7 for Uganda in 2009 and 2017, Sudan in 2009, Niger in 2010, Liberia in 2011 and Ghana in 2009. For economic and production projects, the mean number of projects received by African countries each year is much lower and equal to 0.33 and 0.21 respectively. The maximum numbers of economic and production projects received in a given year are 4 and 3 respectively. Also, on average, African countries received US\$29.9 million of economic ODA each year over the 2000-2014 period. The maximum economic ODA amount received over a given year is equal to US\$919.7 million for Nigeria in 2006.

Mean GDP per capita of African countries between 1999 and 2013 was US\$3780 (2011 US\$) with a high heterogeneity as the standard deviation is equal to US\$4113, the minimum to US\$493 and the maximum to US\$18,172. The total debt service on average, represented $3 \%$ of African countries' GNI. Again, we see a large variability in debt to GNI ratios as, over a given year, the least indebted country had a debt to GNI ratio of $0.06 \%$ and the most indebted country a debt to GNI ratio of $135 \%$. Mean population in the sample is 27.452 million with a minimum of 0.14 million and a maximum of 172.82 million. Almost half of African countries (43.8\%) have adopted English as one of their official languages. 


\begin{tabular}{|c|c|c|c|c|c|}
\hline Variable & Obs. & Mean / \% & Std. Dev. & Min & Max \\
\hline Total ODA projects & 578 & 1.925606 & 2.031725 & 0 & 11 \\
\hline Social ODA projects & 578 & 1.385813 & 1.53015 & 0 & 7 \\
\hline Economic ODA projects & 578 & 0.330449 & 0.691473 & 0 & 4 \\
\hline Economic ODA amount (2014 US\$ million) & 578 & 29.94396 & 111.8945 & 0 & 919.7054 \\
\hline Production ODA projects & 578 & 0.209342 & 0.50931 & 0 & 3 \\
\hline GDP per capita (2011 US\$) & 578 & 3779.709 & 4113.115 & 492.607 & 18171.9 \\
\hline Debt to GNI ratio & 578 & 3.013914 & 7.814267 & .06151 & 135.376 \\
\hline Population (million) & 578 & 20.32137 & 27.452 & 0.13716 & 172.8165 \\
\hline Control of corruption index & 578 & -0.593172 & 0.541979 & -1.56607 & 1.24967 \\
\hline Natural resources rent (\% of GDP) & 578 & 15.54244 & 15.30094 & .001854 & 77.0545 \\
\hline Openness rate (\% of GDP) & 578 & 2.024906 & 6.249 & .0048387 & 83.77744 \\
\hline UNGA voting alignment (\%) & 578 & 72.80586 & 19.25451 & 0 & 95.89041 \\
\hline \multicolumn{6}{|l|}{ Taiwan recognition } \\
\hline Yes (\%) & & 9.69 & & & \\
\hline No (\%) & & 90.31 & & & \\
\hline \multicolumn{6}{|l|}{ English as official language } \\
\hline Yes (\%) & & 43.77 & & & \\
\hline No (\%) & & 56.23 & & & \\
\hline $\begin{array}{l}\text { Total ODA commitments DAC countries } \\
\text { (2015 US\$ million) }\end{array}$ & 578 & 315.3663 & 360.2944 & 3.67707 & 2923.09 \\
\hline $\begin{array}{l}\text { Social ODA commitments DAC countries } \\
\text { (2015 US\$ million) }\end{array}$ & 578 & 221.3089 & 252.5458 & 2.315479 & 2628.62 \\
\hline $\begin{array}{l}\text { Economic ODA commitments DAC countries } \\
\text { (2015 US\$ million) }\end{array}$ & 578 & 58.33875 & 123.1154 & .005865 & 1003.1 \\
\hline $\begin{array}{l}\text { Production ODA commitments DAC countries } \\
\text { (2015 US\$ million) }\end{array}$ & 578 & 35.71864 & 56.13234 & .019719 & 539.7914 \\
\hline
\end{tabular}

Table 3: Descriptive statistics for the sample used in regression analyses

The mean value of the control of corruption index is -0.59 , which indicates a high level of corruption among African countries in our sample over the 1999-2013 period. On average, the natural resources rent was equal to $15.5 \%$ among African countries between 1999 and 2013. The maximum value of the natural resources rent (77.1\%) is reached by the Republic of Congo in 2007. The mean openness rate to China is only $2 \%$ but with large variations across the sample. Among the sample used in the main regression analyses, the highest openness rate to China (83.8\%) is exhibited by Liberia in 2012. UNGA voting alignment of African countries with China is high and equal to $71.5 \%$ on average. In Africa, few countries chose to recognize Taiwan between 1999 and 2013 (only 9.7\% of country-year observations). ODA commitments of DAC countries to African countries in the broad sectors averaged US\$315.4 (2015 US\$) million over the 1999-2013 period. Mean ODA commitments of DAC countries were higher in the social sectors (US\$221.3 million) than in the economic sector (US\$58.34 million) or the production sector (US\$35.7 million). 
Table 4 displays the results of the main analysis using Poisson regressions. Results are expressed as incidence rate ratios (IRR) in order to quantify the impact of the independent variables on the dependent variables. A coefficient higher than 1 (lower than 1 ) indicates a positive (negative) correlation between the dependent and independent variables. More precisely, IRR can be interpreted as multiplying factors that indicate the percentage change in the dependent variable associated with a one-unit increase in the independent variable.

Needs. Lower levels of GDP per capita and debt service ratio are associated with higher levels of Chinese aid, as a whole and for the social sector. Regarding the needs, the logged GDP per capita in African countries is negatively correlated with the total number of Chinese ODA projects when considering the three broad sectors together. When decomposing the analysis by sector, we find that the GDP per capita is significantly associated with the number of social and production projects but not with the number of economic projects nor the amount of economic ODA. The results of the chi-squared tests for coefficients' equality indicate that the level of GDP per capita influences differently the number of social and economic projects received from China. When using the HDI as an alternative measure of needs, we again find a negative correlation between the needs of African countries and the total number of projects in the three broad sectors as well as the number of social and production projects. However, in that case, regression coefficients on the HDI variable only differ between the economic and production sectors. The debt to GNI ratio is negatively associated with the total number of projects in the three broad sectors and the number of social ODA projects but not with the number of projects or the amount of ODA in the economic and production sectors. The correlations between the debt ratio and the total number of projects or the number of social projects are negative. There are however of low magnitude as a one percentage point increase in debt to GNI ratio is associated with only 0.6 and $0.8 \%$ decreases in the total number of projects and the number of social projects respectively. Results of chi-squared tests indicate that the coefficient on the debt to GNI ratio in the social sector is significantly different from the coefficients obtained for the economic and production sectors. Similar to results obtained for traditional donors in the aid allocation literature, the size of the population is negatively correlated with the total number of Chinese ODA projects. 
Chi-squared test for equality of coefficients (ODA projects)

\begin{tabular}{|c|c|c|c|c|c|c|c|c|}
\hline & & & & & & \\
\hline & $\begin{array}{c}\text { Total } \\
\text { projects }\end{array}$ & $\begin{array}{c}\text { Social } \\
\text { projects }\end{array}$ & $\begin{array}{l}\text { Economic } \\
\text { projects }\end{array}$ & $\begin{array}{c}\text { Economic } \\
\text { amount }\end{array}$ & $\begin{array}{c}\text { Production } \\
\text { projects }\end{array}$ & $\begin{array}{c}\text { Social versus } \\
\text { economic }\end{array}$ & $\begin{array}{c}\text { Social versus } \\
\text { production }\end{array}$ & $\begin{array}{c}\text { Economic versus } \\
\text { production }\end{array}$ \\
\hline GDP per capita (log) & $\begin{array}{l}0.771^{* * *} \\
(0.0551)\end{array}$ & $\begin{array}{l}0.754^{* * *} \\
(0.0578)\end{array}$ & $\begin{array}{c}0.918 \\
(0.115)\end{array}$ & $\begin{array}{c}0.934 \\
(0.237)\end{array}$ & $\begin{array}{c}0.706^{* *} \\
(0.106)\end{array}$ & $2.93 *$ & 0.17 & 1.84 \\
\hline Debt to $\mathrm{GNI}$ ratio & $\begin{array}{l}0.994 * * * \\
(0.00201)\end{array}$ & $\begin{array}{l}0.992 * * * \\
(0.00223)\end{array}$ & $\begin{array}{c}0.998 \\
(0.00379)\end{array}$ & $\begin{array}{c}0.992 \\
(0.0168)\end{array}$ & $\begin{array}{c}0.999 \\
(0.00291)\end{array}$ & $4.33^{* *}$ & $3.49^{*}$ & 0.05 \\
\hline Population (log) & $\begin{array}{l}0.894 * * \\
(0.0420)\end{array}$ & $\begin{array}{l}0.901 * * \\
(0.0427)\end{array}$ & $\begin{array}{c}0.865^{*} \\
(0.0695)\end{array}$ & $\begin{array}{c}1.057 \\
(0.139)\end{array}$ & $\begin{array}{c}0.931 \\
(0.0824)\end{array}$ & 0.30 & 0.13 & 0.34 \\
\hline Control of corruption index & $\begin{array}{l}0.785^{* *} \\
(0.0905) \\
\end{array}$ & $\begin{array}{c}0.927 \\
(0.121) \\
\end{array}$ & $\begin{array}{l}0.520 * * * \\
(0.0890)\end{array}$ & $\begin{array}{c}0.650 \\
(0.230) \\
\end{array}$ & $\begin{array}{l}0.478 * * * \\
(0.0951) \\
\end{array}$ & $10.04 * * *$ & $9.35 * * *$ & 0.10 \\
\hline Natural resources rent & $\begin{array}{c}1.008^{*} \\
(0.00453) \\
\end{array}$ & $\begin{array}{c}1.009 * \\
(0.00494) \\
\end{array}$ & $\begin{array}{c}1.012 \\
(0.00774) \\
\end{array}$ & $\begin{array}{c}1.036 * * * \\
(0.0118) \\
\end{array}$ & $\begin{array}{c}0.995 \\
(0.0102) \\
\end{array}$ & 0.24 & 1.27 & 1.36 \\
\hline Openness rate & $\begin{array}{c}1.000 \\
(0.00243) \\
\end{array}$ & $\begin{array}{c}1.003 \\
(0.00279) \\
\end{array}$ & $\begin{array}{l}0.985^{* * *} \\
(0.00538) \\
\end{array}$ & $\begin{array}{l}0.908 * * \\
(0.0400) \\
\end{array}$ & $\begin{array}{c}1.008 \\
(0.00593) \\
\end{array}$ & $10.65^{* * *}$ & 0.64 & $6.28 * *$ \\
\hline UNGA voting alignment & $\begin{array}{l}1.005^{* * *} \\
(0.00198) \\
\end{array}$ & $\begin{array}{c}1.005^{* *} \\
(0.00226) \\
\end{array}$ & $\begin{array}{c}1.008^{*} \\
(0.00441) \\
\end{array}$ & $\begin{array}{c}0.992 \\
(0.0108) \\
\end{array}$ & $\begin{array}{c}1.002 \\
(0.00524) \\
\end{array}$ & 0.24 & 0.29 & 0.49 \\
\hline Taiwan recognition & $\begin{array}{c}0.0366 * * * \\
(0.0264) \\
\end{array}$ & $\begin{array}{c}0.0391 * * * \\
(0.0274) \\
\end{array}$ & $\begin{array}{c}0.0536 * * * \\
(0.0516) \\
\end{array}$ & $\begin{array}{c}0.0972 * * \\
(0.101) \\
\end{array}$ & $\begin{array}{c}0.000000507 * * * \\
(0.000000242) \\
\end{array}$ & 0.36 & $160.80 * * *$ & $101.47 * * *$ \\
\hline English-speaking country & $\begin{array}{c}2.444 * * * \\
(0.250) \\
\end{array}$ & $\begin{array}{c}2.076 * * * \\
(0.225) \\
\end{array}$ & $\begin{array}{c}4.865^{* * *} \\
(1.017) \\
\end{array}$ & $\begin{array}{c}4.068^{* * *} \\
(2.178) \\
\end{array}$ & $\begin{array}{c}2.500 * * * \\
(0.683) \\
\end{array}$ & $16.97^{* * *}$ & 0.43 & $3.34 *$ \\
\hline Total ODA DAC countries (log) & $\begin{array}{c}1.120^{*} \\
(0.0648) \\
\end{array}$ & & & & & & & \\
\hline Social ODA DAC countries (log) & & $\begin{array}{c}1.109 \\
(0.0703)\end{array}$ & & & & & & \\
\hline Economic ODA DAC countries (log) & & & $\begin{array}{c}1.082 \\
(0.0527) \\
\end{array}$ & $\begin{array}{c}1.106 \\
(0.117) \\
\end{array}$ & & & & \\
\hline Production ODA DAC countries (log) & & & & & $\begin{array}{c}1.115^{*} \\
(0.0652) \\
\end{array}$ & & & \\
\hline Year fixed effects & Yes & Yes & Yes & Yes & Yes & & & \\
\hline Observations & 578 & 581 & 578 & 578 & 581 & & & \\
\hline & & Incidence & te ratios; $*$ & $0.10, * * p<$ & $05, * * * p<0.01$ & & & \\
\hline
\end{tabular}

Table 4: Factors associated with Chinese ODA projects and amount 
Merits. Lower control of corruption is associated with more aid, globally and for the economic and production sectors. Turning to merits variables, we find a negative correlation between the control of corruption index in African countries and the total number of Chinese ODA in the three broad sectors. African countries with higher levels of corruption received a higher number of all-sectors Chinese ODA projects between 2000 and 2014. When disaggregating the analysis by sector, we find that this overall association is driven by the economic and production sectors. Indeed, while there is no significant association between corruption and the number of social projects, the analysis highlights negative and significant correlations between the control of corruption index and the number of economic and production projects. For the economic sector, the association between corruption and the volume of Chinese ODA only holds for the number of projects. Moreover, we find that the coefficient on the control of corruption index is significantly different between the social and production or economic sectors while there is no significant difference in this coefficient between the economic and production sectors. The absence of an association between the level of corruption and the number of social projects received is confirmed by the use of an alternative measure of corruption, the corruption perceptions index (see Table C2 in Appendix C). This alternative regression also confirms the positive association between the corruption level and the number of economic and production ODA projects ${ }^{6}$. Again, we find significant differences in the corruption variable coefficient between the social and economic or production sectors but not between the economic and production sectors. When using alternative measures of governance, we find a negative correlation between the regulatory quality index and the number of projects in the economic sector and a negative correlation between the rule of law index and the number of Chinese ODA projects in the production sector (see Table C3 and C4 in Appendix D).

Chinese interests. A high endowment in natural resources is a good context for benefiting from more Chinese ODA. On the contrary, foreign policy divergences with China have globally the opposite effect. Regarding Chinese economic interests, regression analyses point to a positive correlation between the natural resources rent in African countries and the total number of Chinese ODA projects. Overall, a one percentage point increase in the natural resources rent is associated with a $0.8 \%$ increase in the number of Chinese ODA projects received. If we disaggregate the analysis by sector, we see that this association is only significant for the social and economic sectors. However, the results of coefficients equality tests show no differences between the coefficients of the natural resources rent by sector. The association between Chinese aid and the natural resources rent is highly significant and of greater magnitude for the amount of economic ODA. A one percentage point increase in the natural resources rent is associated with a $3.6 \%$ increase in Chinese economic ODA amount. The openness rate of African countries to China is not significantly correlated with the number of ODA projects received in the three broad sectors. This lack of significance is explained by the existence of opposite correlations between the openness rate to China and the number of Chinese ODA projects depending on the sector considered. Our findings highlight positive, but not significant, correlations between the openness rate to China and the number of social or production ODA projects while they point to negative, significant and much stronger correlations between this variable and the number or the amount of economic

\footnotetext{
${ }^{6} \mathrm{~A}$ higher value of the corruption perceptions index translates a lower level of corruption. Then a negative correlation between the corruption perceptions index and the volume of aid received indicate a positive association between the level of corruption and the volume of aid received.
} 
projects. We also find that the coefficients on the openness rate significantly differ between the economic sector and the social or production sectors.

Taiwan recognition by an African country almost systematically excludes it from the receipt of Chinese ODA, whatever the sector. Indeed, we find negative and very strong correlations between Taiwan recognition and Chinese ODA in all broad sectors. The association appears to be of greater magnitude for the production sector while we find no difference in the effect of Taiwan recognition on the receipt of social and economic projects. For the second Chinese political interests' variable, results show a positive correlation between the total number of ODA projects and UNGA voting alignment of African countries with China. A sectorial analysis indicates that the numbers of social and economic ODA projects are correlated with this variable but not ODA projects in the production sector. The magnitude of these correlations are however low since a one percentage point increase in UNGA voting alignment with China is only associated with $0.5 \%$ increases in social ODA projects and all-sectors ODA projects and a $0.8 \%$ increase in economic ODA projects. Moreover, we find no significant difference in the coefficients on the voting alignment variable by sectors.

Regarding the relation between Chinese and DAC donors ODA, our results show that Chinese aid and aid commitments of DAC countries are positively correlated in the production sector but not in the social or economic sectors.

Robustness of results. Table 5 displays the results of the alternative regression analysis using Tobit specifications. Results of regression analyses are presented as raw coefficients. These alternative specifications confirm our results. For the needs variables, we again find negative correlations between the GDP per capita and the total number of ODA projects as well as the number of social ODA projects while no such association is found in the economic sector. However, the association between the level of income and the number of production ODA projects is no more significant when using Tobit regressions. Again, the debt to GNI ratio is found to be negatively correlated with the total number of ODA projects and the number of social ODA projects while no significant association is found for the number of economic and production projects. Regarding the merits variable, we again find a negative correlation between the control of corruption index and the total number of ODA projects in the three broad sectors, the number of economic projects and the number of production projects. We now also find a negative correlation between this governance variable and the amount of economic ODA. Results of Tobit regressions regarding the natural resources rent and the political interests' variables ${ }^{7}$ are identical to those obtained using Poisson regressions. Important differences emerge with Poisson specifications only for the openness rate variable. Results again indicate negative correlations between the openness rate to China and the number and amount of economic ODA projects received. However, the positive correlations between the openness rate to China and the number of ODA projects in the social and production sectors are now significant. However, results of chi-squared tests for coefficients equality by sector are the same as those obtained for Poisson regressions. The coefficients on the openness rate variable are significantly different in the economic sector compared to the social or production sector while there is no significant difference between the social and production sectors.

\footnotetext{
${ }^{7}$ The Taiwan recognition variable was omitted in the estimation of the Tobit model production ODA projects given convergence issues.
} 


\begin{tabular}{|c|c|c|c|c|c|c|c|c|}
\hline & \multirow[b]{2}{*}{$\begin{array}{c}\text { Total } \\
\text { projects }\end{array}$} & \multirow[b]{2}{*}{$\begin{array}{c}\text { Social } \\
\text { projects }\end{array}$} & \multirow[b]{2}{*}{$\begin{array}{l}\text { Economic } \\
\text { projects }\end{array}$} & \multirow[b]{2}{*}{$\begin{array}{c}\text { Economic } \\
\text { amount }\end{array}$} & \multirow[b]{2}{*}{$\begin{array}{c}\text { Production } \\
\text { projects }\end{array}$} & \multicolumn{3}{|c|}{$\begin{array}{l}\begin{array}{l}\text { Chi-squared test for equality of coefficients (ODA } \\
\text { projects) }\end{array} \\
\end{array}$} \\
\hline & & & & & & $\begin{array}{c}\text { Social versus } \\
\text { economic }\end{array}$ & $\begin{array}{l}\text { Social versus } \\
\text { production }\end{array}$ & $\begin{array}{c}\text { Economic versus } \\
\text { production }\end{array}$ \\
\hline GDP per capita (log) & $\begin{array}{c}-0.625^{* * *} \\
(0.173)\end{array}$ & $\begin{array}{c}-0.537^{* * *} \\
(0.149)\end{array}$ & $\begin{array}{l}-0.212 \\
(0.154)\end{array}$ & $\begin{array}{l}-23674750.5 \\
(33137936.9)\end{array}$ & $\begin{array}{c}-0.248 \\
(0.155)\end{array}$ & $4.27^{* *}$ & 2.16 & 0.03 \\
\hline Debt to $\mathrm{GNI}$ ratio & $\begin{array}{l}-0.0177^{* *} \\
(0.00823) \\
\end{array}$ & $\begin{array}{c}-0.0194 * * * \\
(0.00598) \\
\end{array}$ & $\begin{array}{l}-0.00530 \\
(0.00523) \\
\end{array}$ & $\begin{array}{l}-3724084.2^{*} \\
(2050567.9) \\
\end{array}$ & $\begin{array}{c}0.00492 \\
(0.00406) \\
\end{array}$ & $12.63^{* * *}$ & $11.79 * * *$ & 2.48 \\
\hline Population (log) & $\begin{array}{c}-0.293^{* *} \\
(0.149) \\
\end{array}$ & $\begin{array}{c}-0.211^{*} \\
(0.111) \\
\end{array}$ & $\begin{array}{c}-0.224^{* *} \\
(0.102) \\
\end{array}$ & $\begin{array}{l}-24194926.4 \\
(17382078.7) \\
\end{array}$ & $\begin{array}{l}-0.0315 \\
(0.104) \\
\end{array}$ & 0.01 & 1.31 & 1.63 \\
\hline Control of corruption index & $\begin{array}{c}-0.690 * * \\
(0.325) \\
\end{array}$ & $\begin{array}{l}-0.216 \\
(0.272)\end{array}$ & $\begin{array}{c}-0.734 * * * \\
(0.238) \\
\end{array}$ & $\begin{array}{l}-82266560.3^{*} \\
(42018027.9) \\
\end{array}$ & $\begin{array}{c}-0.994 * * * \\
(0.278) \\
\end{array}$ & $2.76^{*}$ & $5.53^{* *}$ & 0.53 \\
\hline Natural resources rent & $\begin{array}{l}0.0183^{*} \\
(0.0104)\end{array}$ & $\begin{array}{c}0.0145 \\
(0.00926)\end{array}$ & $\begin{array}{c}0.0212 * * * \\
(0.00802)\end{array}$ & $\begin{array}{c}4140331.9 * * * \\
(1514335.3)\end{array}$ & $\begin{array}{l}-0.00142 \\
(0.0124) \\
\end{array}$ & 0.67 & 0.91 & 1.85 \\
\hline Openness rate & $\begin{array}{l}0.0208^{* *} \\
(0.00954)\end{array}$ & $\begin{array}{c}0.0274 * * * \\
(0.00785)\end{array}$ & $\begin{array}{c}-0.0203 * * * \\
(0.00654)\end{array}$ & $\begin{array}{c}-5923000.0 * * * \\
(1436475.5)\end{array}$ & $\begin{array}{c}0.0139 * \\
(0.00740)\end{array}$ & $30.68^{* * *}$ & 2.35 & $8.77^{* * *}$ \\
\hline UNGA voting alignment & $\begin{array}{l}0.00970 * \\
(0.00571) \\
\end{array}$ & $\begin{array}{l}0.00810^{*} \\
(0.00463)\end{array}$ & $\begin{array}{l}0.0123^{* *} \\
(0.00548) \\
\end{array}$ & $\begin{array}{c}801000.6 \\
(1409431.0) \\
\end{array}$ & $\begin{array}{c}0.00852 \\
(0.00720) \\
\end{array}$ & 0.44 & 0.00 & 0.13 \\
\hline Taiwan recognition & $\begin{array}{c}-5.921 * * * \\
(0.702)\end{array}$ & $\begin{array}{c}-4.511 * * * \\
(0.603)\end{array}$ & $\begin{array}{c}-2.930 * * * \\
(0.763)\end{array}$ & $\begin{array}{c}-404026579.2 * * * \\
(136353761.6) \\
\end{array}$ & & $5.64^{* *}$ & & \\
\hline English-speaking country & $\begin{array}{c}2.351^{* * *} \\
(0.320)\end{array}$ & $\begin{array}{c}1.501^{* * *} \\
(0.254)\end{array}$ & $\begin{array}{c}2.042^{* * *} \\
(0.284)\end{array}$ & $\begin{array}{c}286511625.4^{* * * *} \\
(50767199.7)\end{array}$ & $\begin{array}{c}0.961^{* * *} \\
(0.284)\end{array}$ & 2.58 & 2.49 & $6.32 * *$ \\
\hline Total ODA DAC countries (log) & $\begin{array}{c}0.265 \\
(0.171) \\
\end{array}$ & & & & & & & \\
\hline Social ODA DAC countries (log) & & $\begin{array}{c}0.197 \\
(0.150) \\
\end{array}$ & & & & & & \\
\hline Economic ODA DAC countries (log) & & & $\begin{array}{c}0.0763 \\
(0.0552)\end{array}$ & $\begin{array}{c}19573426.4^{* *} \\
(9853355.8)\end{array}$ & & & & \\
\hline Production ODA DAC countries (log) & & & & & $\begin{array}{l}0.144^{* *} \\
(0.0687)\end{array}$ & & & \\
\hline Constant & $\begin{array}{l}1.973 * * * \\
(0.0876)\end{array}$ & $\begin{array}{l}1.687^{* * *} \\
(0.0692)\end{array}$ & $\begin{array}{l}1.738 * * * \\
(0.0987)\end{array}$ & $\begin{array}{c}313540736.4^{* * *} \\
(36194796.7)\end{array}$ & $\begin{array}{c}1.750 * * * \\
(0.117)\end{array}$ & & & \\
\hline Year fixed effects & Yes & Yes & Yes & Yes & Yes & & & \\
\hline Observations & 578 & 581 & 578 & 578 & 581 & & & \\
\hline & & Standard er & s in parentr & $\operatorname{ses}^{*} \mathrm{p}<0.10,{ }^{* *} \mathrm{p}$ & $05, * * * p<0$ & & & \\
\hline
\end{tabular}

Table 5: Tobit specifications for factors associated with Chinese ODA volume 


\subsection{Results of regressions analyses using aid shares}

Table 6 reports the results of fractional probit regressions using aid shares as dependent variables. Results are expressed as raw coefficients.

Results are confirmed by the analyses based on aid shares (number of projects and amounts). Results of regression analyses using aid shares are very similar to those obtained using absolute volumes of Chinese ODA. For needs variables, we again find negative correlations between the GDP per capita in African countries and the share of Chinese ODA projects in the three broad sectors as well as the shares of social and production ODA projects. For the debt to GNI ratio results are identical to the previous analysis. The debt ratio is negatively correlated with the share of total projects in the three broad sectors and the share of social projects. Results using aid shares again point to a negative association between the size of the population and Chinese aid allocation. The population size is negatively correlated with the shares of Chinese ODA projects received globally and in the social and economic sectors.

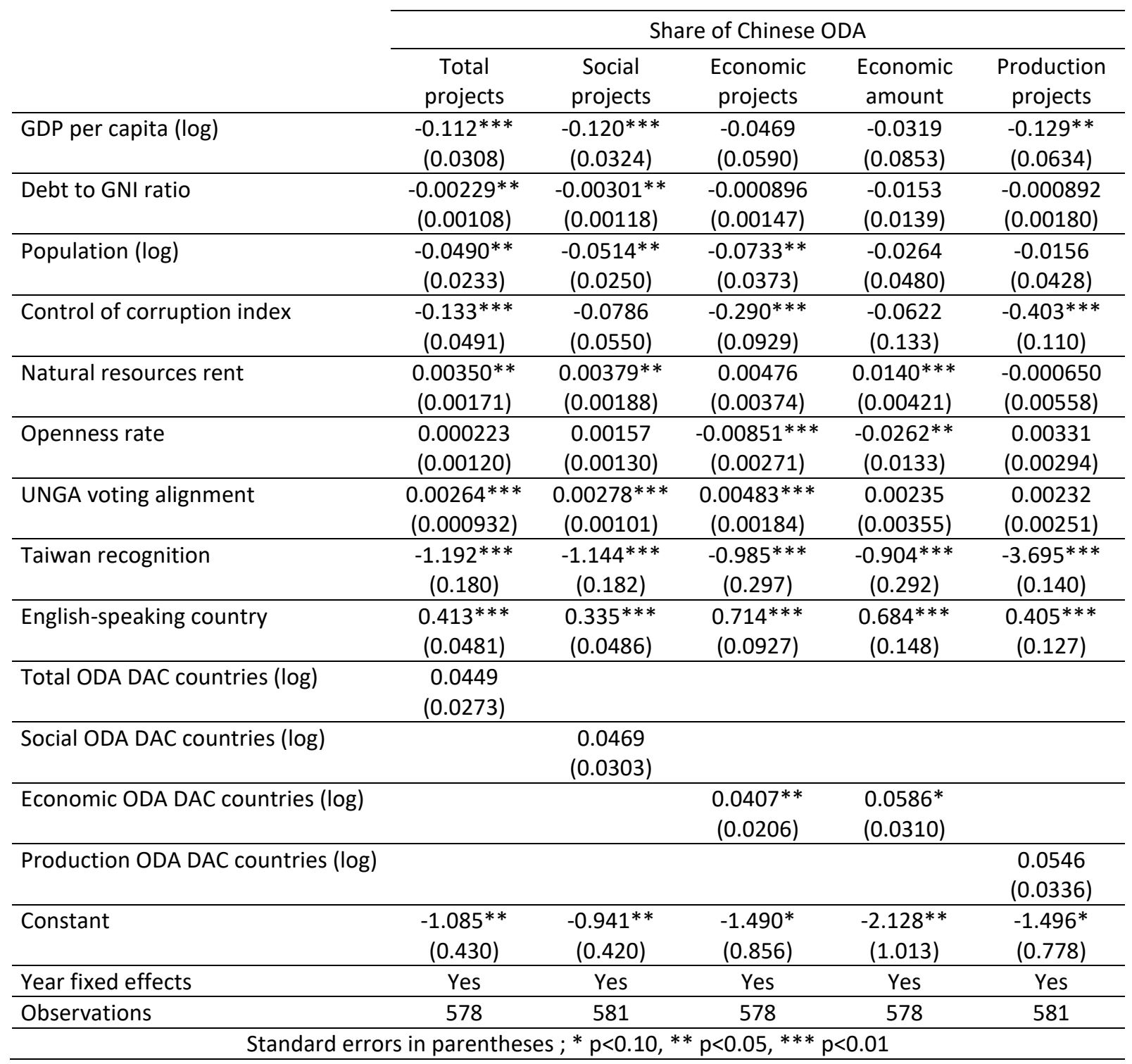

Table 6: Factors associated with Chinese ODA shares 
Regarding the merits variable, our results indicate that the control of corruption index is negatively correlated with the shares of economic and production projects. These results are identical to those obtained using the number of aid projects. For Chinese economic interests' variables, results are perfectly similar to those obtained when studying the absolute volume of Chinese aid. The natural resources rent is positively correlated with the share of all-sectors projects and with the shares of social projects and economic amounts received. As in the previous analysis, the openness rate to China is negatively correlated with the shares of economic projects and amount but not correlated with the shares of social and production projects. Similar to what was found in the analysis using aid volumes, Taiwan recognition is negatively and very strongly correlated with the shares of Chinese ODA projects in all individual sectors as well as with the share of economic ODA amount. Once again, results indicate a positive correlation between UNGA voting alignment with China and the share of social projects, the share of production projects and the share of all-sectors ODA projects. The only variables for which results differ between the two analyses (volume of aid versus share of total Chinese aid), are DAC countries ODA commitments. While we previously found a positive correlation between DAC countries and Chinese aid volumes in the production sector, we now find this positive correlation in the economic sector.

\section{Discussion}

This paper provides a sectorial analysis of the determinants of Chinese aid allocation in African countries. We consider three types of ODA sectors; the social infrastructure and services sector, the economic infrastructure and services sector and the production sector. We study the differentiated impacts of African countries needs and merits as well as Chinese interests on aid allocation decisions of China in these three broad sectors. Our results show the need of disaggregating the analysis by sector when studying the determinants of Chinese ODA in Africa. Indeed, any analysis considering allsectors ODA might lead to misleading results as we find that needs, merits and interests' variables exert different influences on Chinese aid allocation decisions depending on the sector considered. Our main results are summarized thereafter.

First, GDP per capita matters for getting Chinese ODA in the social and production sectors but not in the economic sector. Our results point to a negative association between the GDP per capita in African countries and the receipt of all-sectors Chinese ODA projects. This result is coherent with the previous literature regarding Chinese aid allocation. Indeed, Dreher and Fuchs (2015) find that total Chinese ODA projects and amount are negatively correlated with the GDP per capita of recipient countries over the 1996-2006 period while Dreher et al. (2018) find that GDP per capita in African countries is negatively correlated with the total amount of all-sectors ODA they received from China between 2000 and 2013. Broich (2017) also finds a negative correlation between the GDP per capita and the amount of Chinese official development finance received by African countries between 2000 and 2011. In addition, our results show that this overall association is driven by projects received in the social and, to a lesser extent, production sectors. We therefore find partial support four our first hypothesis since aid in the social sector is more related to the needs of African countries compared to aid in the economic sector but not compared to aid in the production sector.

Second, Chinese ODA to the economic and production sectors is rather moving towards countries with weak quality of governance while this is not the case for the social sector. Previous studies on the 
determinants of Chinese official development finance have found that governance in recipient countries neither influences the global volume of Chinese aid in terms of projects' number or amount (Dreher and Fuchs, 2015; Broich, 2017; Dreher et al. 2018) nor Chinese health aid projects' number or amount (Guillon and Mathonnat, 2017). Our results are coherent with this literature. Indeed, on the four governance indicators tested (corruption perception index, control of corruption, regulatory quality and rule of law indexes), we only find a significant correlation between the overall number of Chinese ODA projects and the control of corruption index. However, if our results confirm the global pattern for the social sector, it rejects it for the economic and production sectors. We find that the quality of governance in African countries; as measured by two alternative indicators of corruption; is negatively correlated with Chinese aid allocation in the economic and production sectors but unrelated with Chinese ODA in the social sector. Moreover, results of coefficients' equality tests by sector confirm the specificity of the social sector. These results confirm our second hypothesis according to which countries with lower governance quality do not receive less aid, whatever the sector. We even find that African countries with weaker political governance tend to benefit more from Chinese ODA in the economic and production sectors. This finding might appear surprising but is however in line with results found in the literature studying the determinants of Chinese FDI. For example, Buckley et al. (2007) find that Chinese FDI over the 1984-2001 period is associated with lower levels of political stability in recipient countries. Sanfilippo (2010) investigates the determinants of Chinese FDI in African countries between 1998 and 2007 and also finds that Chinese FDIs are more important in African countries with lower civil liberties. In several papers, Kolstad and Wiig $(2011,2012)$ show that Chinese FDIs are attracted to African countries with a combination of large natural resources and poor institutions as measured by the rule of law index. This result is confirmed, especially for state-owned enterprises, by the analysis of Amighini et al. (2013). More recently, Mourao (2018) also find that African countries with lower regulatory quality indexes were more efficient in attracting Chinese FDI over the 2003-2010 period. Then, Chinese ODA allocation decisions tend to follow the same motivations as FDI allocation decisions in the economic and production sectors.

Third, our results indicate that African countries with high endowments of natural resources tend to receive more Chinese ODA when considering the three broad sectors altogether. This finding contradicts those of Dreher and Fuchs ${ }^{8}$ (2015) and Dreher et al. (2018) who find no association between oil endowment of recipient countries and Chinese ODA ${ }^{9}$. However, it confirms the results of Broich (2017) who finds that oil-rich African countries tend to benefit from more Chinese development finance. Our results indicate that the association between the natural resources rent and the volume of Chinese ODA holds in the social and economic sectors but not in the production sector. This association is nevertheless of much higher significance and magnitude for the amount of economic ODA compared to the number of social projects. We therefore find mixed support for our third hypothesis since the endowment in natural resources appears more important in driving economic ODA compared to social ODA but appears unrelated to ODA in the productions sector. Our results also point to a lack of association between the openness rate to China and the number of all-sectors

\footnotetext{
${ }^{8}$ Based on the previous version of the database.

${ }^{9}$ Differences in results might partly be owing to the fact that we use the number of ODA projects, rather than ODA amount as in Dreher and Fuchs (2015) and Dreher et al. (2018), given the high number of social and production sectors' ODA projects lacking financial valorization. Moreover, we do not consider all ODA projects as in Dreher and Fuchs (2015) and Dreher et al. (2018) but only projects related to the social, economic and production sectors that constitute 84\% of all Chinese ODA projects to African countries between 2000 and 2014.
} 
Chinese aid projects received by African countries. This is in line with the results of Dreher et al. (2018) who find no association between the volume of trade with China and the total amount of ODA received by African countries. However, it contradicts the results of Dreher and Fuchs (2015) who find, over the 1996-2006 period, a positive correlation between China's total exports to a recipient country and the number of Chinese ODA projects it received. If a sectorial analysis of Chinese ODA allocation decisions is not conducted, global results might be misleading for the impact of economic ties with China on the receipt of Chinese ODA. Indeed, we find that the openness rate to China is positively correlated with the number of social and production projects (insignificantly in the Poisson model, but significantly in the Tobit specifications), while it is negatively and significantly correlated with the number and amount of Chinese ODA projects in the economic sector. Moreover, we find that the coefficients on the openness rate to China variable are similar in the social and production sectors but significantly different than the coefficient obtained for the economic sector. Broich (2017) also finds a negative correlation between the volume of imports from China in African countries and the volume of Chinese official development finance they receive. According to Broich (2017), this negative correlation could arise since "the scope for tying aid to purchase goods from China is especially high in those countries that have very weak trade relationships with China to begin with". This explanation is coherent with our results as we only find a negative correlation between the openness rate and the number of ODA projects received in the economic sector where aid and trade can more easily be tied.

Fourth, as observed in all previous studies of Chinese ODA determinants, our results indicate that adherence to the One-China policy is a necessary condition to benefit from Chinese ODA, overall and in all individual sectors. UNGA voting alignment with China is also positively correlated with the number of ODA projects received when considering the three broad sectors together. This result differs from those obtained by Dreher and Fuchs (2015) who find no association between UNGA voting alignment with China and all-sectors Chinese ODA amount and projects received over the 1996-2006 period. It also differs from findings of Broich (2017) and Dreher et al. (2018) who show that the total amount of Chinese ODA or OOF received by African countries in the 2000's is independent of their UNGA voting alignment with China. Again, our analysis stresses out the need to disaggregate the analysis by ODA sectors when studying the factors associated with Chinese ODA. Indeed, UNGA voting alignment of African countries with China appears to be associated with the number of social ODA projects (which more often correspond to technical assistance projects in the form of training, scholarships or sending of Chinese experts) and, to a lesser extent, to the number of economic ODA projects. However, it appears unrelated to the amount of economic ODA or the number of production projects received. We therefore find some support to our fourth hypothesis since aid allocation in the social sector is more influenced by Chinese political interest, as measured by UNGA voting alignment, compared to aid in the production sector. However, we do not find that Chinese political interests play a more important role in aid allocation in the social sector compared to the economic sector. Dreher et al. (2016) also study the role of political factors on the allocation of Chinese aid in African countries. Using geocoded Chinese aid data, the authors investigate whether the subnational allocation of Chinese aid is associated with the birth region of political leaders. Results of this analysis indicate that the overall number and amount of Chinese ODA projects received by birth regions of leaders are significantly higher. The authors next decompose their analysis by ODA broad sectors and find this effect to be stronger for projects in the social and production sectors compared to the economic sector. Comparing these results to our findings, it appears that political interests of both African and Chinese leaders (measured by the UNGA voting alignment for the latter) drive the allocation of Chinese social ODA 
projects in Africa. However, while we find that UNGA voting alignment is unrelated to the allocation of Chinese production ODA, Dreher et al. (2016) find that the political interests of African leaders are important for the subnational allocation of ODA production projects received from China.

Overall, it appears that Chinese ODA allocation decisions rely on different motivations depending on the sector considered. While Chinese ODA in the social sector is more responsive to the economic needs of recipient countries, it also appears to be driven by foreign policy considerations. We find some evidence that Chinese economic interests, in particular for natural resources acquisition, are associated with China's ODA allocation in general. However, this overall association appears to be driven by the economic and social sectors while Chinese economic interests are not associated with its aid allocation to African countries in the production sector. Finally, while governance quality in recipient countries is not associated with ODA in the social sector, our results show that China tends to allocate more economic and production ODA to African countries with weaker institutions similar to what is observed for its FDI allocation.

Our work is not without limitations. Chinese ODA data used in the analysis are less complete than those available for OECD countries or international organizations. In particular, the financial valorisation of ODA is lacking for a high number of projects. This led us to restrict the analysis of ODA amount to the economic sector where the financial valorisation of ODA projects is less often missing. However, Chinese official ODA data are very sparse due to a large fragmentation of funding agencies (China Ministry of Commerce, Export-Import Bank of China, China Development Bank and various provincial agencies among others) and possibly owing to a will of Chinese authorities to retain specific information on overseas development activities. Despite the limitations of the data we use, we believe our results bring new and important information on the underlying motivations of Chinese aid allocation in the absence of comprehensive official ODA data, one strong conclusion of this study being, as we have pointed out, the need to disaggregate the analysis by ODA sectors.

\section{Conclusion and policy implications}

For two decades, new donors; such as India, China, Saudi Arabia and Brazil; have emerged in parallel to traditional DAC donors. This changing aid landscape is likely to impact the political, economic and social environment in recipient countries and to induce a shift in international order (Woods, 2008; Dreher et al., 2018). The rise in aid provided by non-traditional donors has raised both hopes and fears.

On the "hope" side, recent development experiences of new donors might give them more legitimacy and efficiency in providing aid as a part of South-South cooperation (Dreher et al., 2011). Moreover, the emergence of new aid actors has been seen as an opportunity to revitalize the aid field by some researchers (Gulrajani and Swiss, 2017). On the "fear" side, the emergence of new donors has led to a higher fragmentation of international aid. This fragmentation has been considered to complicate the coordination of the global aid effort (Kragelund, 2008; Chandy and Kharas, 2011; Gulrajani and Swiss, 2017) and the threat that it imposes on the coherence of aid policies and programs has been underlined in many international donor conferences since the 1995 DAC meeting in Paris. Moreover, new donors are often seen as encouraging poor policies and institutions in recipient countries by positioning themselves as alternative donors for countries unwilling to meet the governance requirements of traditional donors (Manning, 2006; Woods, 2008). Finally, new donor countries are 
sometimes thought to adopt only the form but not the functions of international donors (Gulrajani and Swiss, 2017). Indeed, some authors consider that new donors, especially China, mainly allocate aid to seek economic and political influence, this aid being poorly targeted to the neediest countries (Alden, 2005; Naim, 2007; Gulrajani and Swiss, 2017).

Despite a burgeoning literature on the determinants and effectiveness of new donors' aid (Neumayer, 2003; Dreher et al., 2011; Fuchs and Vadlamannati, 2013; Dreher et al., 2015, Broich, 2017; Dreher et al., 2018), more research is needed to understand how the rise of new donors has affected and will continue to affect the international aid architecture and the social, economic and institutional development of recipient countries. In particular, more disaggregated analyses of new donors' aid are needed both by type of financial flows, as new donors more often use hybrid forms of development finance, and by aid sector, since the new donors' motivations might differ for social, economic and production aid. Our article constitutes an attempt toward a better understanding of new donors' aid motivations by aid sector in focusing on Chinese ODA to African countries. We find that Chinese motivations for ODA allocation diverge depending on the sector considered. Several of our results raise issues with important policy implications.

The positive correlations we find between DAC donors and Chinese aid in the production and economic sectors suggest that there exist a room and a need for coordination between Chinese aid and aid of traditional donors. Until now, China has been very reluctant to participate in the coordination process of ODA at the international level and at the countries level. However, such coordination would be in line with the agenda of action of the Addis-Abeba conference (2015) on development financing and could promote synergies between aid of traditional and new donors, increasing the global aid effectiveness.

China has always stated to allocate its aid in response to the needs expressed by recipient countries. We indeed find a negative correlation between the GDP per capita in African countries and the volume of Chinese aid they receive in the social sector, and to a lesser extent in the production sector. However, we do not find any significant correlation between this measure of economic needs and the volume of aid received in the economic sector. These results question to what extent Chinese aid really follows the priorities of recipient countries in all aid sectors, even when this aid is targeted to needs: all the needs are not a priority in budget, socioeconomic policy and strategy. Moreover, the positive correlation we find between the level of corruption and the receipt of economic and production projects, raises doubt on whether the future implications of Chinese current aid projects in terms of recurrent expenditures are properly taken into account by recipient countries in their medium-term expenditure frameworks. If not, it undermines the effectiveness of the Chinese aid and the sustainability of its results. This preoccupation is reinforced by the unknown impact of Chinese aid, which largely relies on loans, on the medium-term debt sustainability of African countries which is a growing matter of concern in numerous of them.

As we find indications that Chinese aid allocation decisions tend to favour both resource-rich countries and countries with a lower level of governance, we might also wonder if Chinese aid - following the principle of non-interference which implies no conditionality - do not push indirectly some recipient countries to distance themselves from the sound and transparent financial management principles of natural resources advocated by international organizations such as the International Monetary Fund (IMF, 2007) or international initiative as the Extractive Industries Transparency Initiative. 


\section{References}

Acht, M., Mahmoud, T. O., \& Thiele, R. (2015). Corrupt governments do not receive more state-tostate aid: Governance and the delivery of foreign aid through non-state actors. Journal of Development Economics, 114, 20-33.

Alden, C. (2005). Red star, black gold. Review of African Political Economy, 32(104/105), 415-419.

Amighini, A. A., Rabellotti, R., \& Sanfilippo, M. (2013). Do Chinese state-owned and private enterprises differ in their internationalization strategies?. China Economic Review, 27, 312-325.

Anderson, J. E., \& Yotov, Y. V. (2016). Terms of trade and global efficiency effects of free trade agreements, 1990-2002. Journal of International Economics, 99, 279-298.

Berthélemy, J. C., \& Tichit, A. (2004). Bilateral donors' aid allocation decisions-a three-dimensional panel analysis. International Review of Economics \& Finance, 13(3), 253-274.

Berthélemy, J. C. (2006). Bilateral donors' interest vs. recipients' development motives in aid allocation: do all donors behave the same?. Review of Development Economics, 10(2), 179-194.

Bräutigam, D. (2009). The Dragon's Gift: the Real Story of China in Africa.

Bräutigam, D. (2010). China, Africa and the international aid architecture. African development bank.

Broich, T. (2017). Do authoritarian regimes receive more Chinese development finance than democratic ones? Empirical evidence for Africa. China Economic Review, 46, 180-207.

Buckley, P. J., Clegg, L. J., Cross, A. R., Liu, X., Voss, H., \& Zheng, P. (2007). The determinants of Chinese outward foreign direct investment. Journal of international business studies, 38(4), 499-518.

Cameron, A. C., \& Trivedi, P. K. (2005). Microeconometrics: methods and applications. Cambridge university press.

Carter, B. (2017). A literature review on China's aid.

Cashel-Cordo, P., \& Craig, S. G. (1997). Donor preferences and recipient fiscal behavior: a simultaneous analysis of foreign aid. Economic Inquiry, 35(3), 653-671.

Chandy, L., \& Kharas, H. (2011). Why can't we all just get along? The practical limits to international development cooperation. Journal of International Development, 23(5), 739-751.

Clist, P. (2011). 25 years of aid allocation practice: Whither selectivity?. World Development, 39(10), 1724-1734.

Didier, L. (2016). Economic diplomacy: The "one-China policy" effect on trade. China Economic Review.

Dollar, D. (2016). China's engagement with Africa: From natural resources to human resources. Washington, DC: The Brookings Institution.

Dollar, D., \& Levin, V. (2006). The increasing selectivity of foreign aid, 1984-2003. World development, 34(12), 2034-2046. 
Dreher, A., Nunnenkamp, P., \& Thiele, R. (2011). Are 'new'donors different? Comparing the allocation of bilateral aid between nonDAC and DAC donor countries. World Development, 39(11), 1950-1968.

Dreher, A., \& Fuchs, A. (2015). Rogue aid? An empirical analysis of China's aid allocation. Canadian Journal of Economics/Revue canadienne d'économique, 48(3), 988-1023.

Dreher, A., Fuchs, A., Hodler, R., Parks, B., Raschky, P., \& Tierney, M. J. (2016). Aid on demand: African leaders and the geography of China's foreign assistance.

Dreher, Axel, Andreas Fuchs, Bradley Parks, Austin M. Strange, and Michael J. Tierney. (2017). Aid, China, and Growth: Evidence from a New Global Development Finance Dataset. AidData Working Paper \#46. Williamsburg, VA: AidData. Version 1.0. Retrieved from http://aiddata.org/data/chineseglobal-official-finance-dataset.

Dreher, A., Fuchs, A., Parks, B., Strange, A. M., \& Tierney, M. J. (2018). Apples and dragon fruits: the determinants of aid and other forms of state financing from China to Africa. International Studies Quarterly, 62(1), 182-194.

Esser, D. E., \& Bench, K. K. (2011). Does global health funding respond to recipients' needs? Comparing public and private donors' allocations in 2005-2007. World Development, 39(8), 1271-1280.

Fernandes, A. M., Freund, C., \& Pierola, M. D. (2016). Exporter behavior, country size and stage of development: Evidence from the exporter dynamics database. Journal of Development Economics, $119,121-137$.

Fielding, D. (2011). Health aid and governance in developing countries. Health economics, 20(7), 757769.

Fink, G., \& Redaelli, S. (2009). Determinants of international emergency aid-humanitarian need only?. The World Bank.

Fuchs, A., \& Vadlamannati, K. C. (2013). The needy donor: An empirical analysis of India's aid motives. World Development, 44, 110-128.

Gulrajani, N., \& Swiss, L. (2017). Why do countries become donors? Assessing the drivers and implications of donor proliferation. Research reports and studies, London: ODI. En goo. gl/ivv4Rc.

Grépin, K. A., Fan, V. Y., Shen, G. C., \& Chen, L. (2014). China's role as a global health donor in Africa: what can we learn from studying under reported resource flows?. Globalization and Health, 10(1), 1.

Grimm, S. (2014). China-Africa Cooperation: promises, practice and prospects. Journal of Contemporary China, 23(90), 993-1011.

Guillon M., Mathonnat J. (2017) "Is there a strategy in China's health official development assistance to African countries?", Études et Documents, $n^{\circ} 20$, CERDI.

Hoeffler, A., \& Outram, V. (2011). Need, Merit, or Self-Interest-What Determines the Allocation of Aid?. Review of Development Economics, 15(2), 237-250.

International Monetary Fund. Fiscal Affairs Dept. (2007). Guide on resource revenue transparency. 
Kaufmann, D., Kraay, A., \& Mastruzzi, M. (2011). The worldwide governance indicators: methodology and analytical issues. Hague Journal on the Rule of Law, 3(02), 220-246.

Kimura, H., \& Todo, Y. (2010). Is foreign aid a vanguard of foreign direct investment? A gravity-equation approach. World Development, 38(4), 482-497.

Kjøllesdal, K., \& Welle-Strand, A. (2010). Foreign aid strategies: China taking over?. Asian Social Science, 6(10), 3.

Kolstad, I., \& Wiig, A. (2011). Better the devil you know? Chinese foreign direct investment in Africa. Journal of African Business, 12(1), 31-50.

Kolstad, I., \& Wiig, A. (2012). What determines Chinese outward FDI?. Journal of World Business, 47(1), 26-34.

Kragelund, P. (2008). The return of non-DAC donors to Africa: new prospects for African development?. Development policy review, 26(5), 555-584.

Lee, S. A., \& Lim, J. Y. (2014). Does international health aid follow recipients' needs? Extensive and intensive margins of health aid allocation. World Development, 64, 104-120.

Liao, J., Cheng, F., Harris, A., \& Xu, D. (2018). The new face of China's foreign aid: where do we go from here?. The Lancet, 392(10148), 636.

Lin, S., Gao, L., Reyes, M., Cheng, F., Kaufman, J., \& El-Sadr, W. M. (2016). China's health assistance to Africa: opportunism or altruism?. Globalization and Health, 12(1), 83.

Luo, L., Qi, Z., \& Hubbard, P. (2017). Not looking for trouble: Understanding large-scale Chinese overseas investment by sector and ownership. China Economic Review, 46, 142-164.

Manning, R. (2006). Will 'Emerging Donors' change the face of international cooperation?. Development policy review, 24(4), 371-385.

McGillivray, M. (2003). Modelling aid allocation: issues, approaches and results (No. 2003/49). WIDER Discussion Papers//World Institute for Development Economics (UNU-WIDER).

Mourao, P. R. (2018). What is China seeking from Africa? An analysis of the economic and political determinants of Chinese Outward Foreign Direct Investment based on Stochastic Frontier Models. China Economic Review, 48, 258-268.

Naim, M. (2007). Rogue aid. Foreign policy, (159), 96.

Neumayer, E. (2003). What factors determine the allocation of aid by Arab countries and multilateral agencies?. Journal of Development Studies, 39(4), 134-147.

Nunnenkamp, P., \& Öhler, H. (2011). Aid allocation through various official and private channels: Need, merit, and self-interest as motives of German donors. World Development, 39(3), 308-323.

Papke, L. E., \& Wooldridge, J. M. (1996). Econometric methods for fractional response variables with an application to 401 (k) plan participation rates. Journal of Applied Econometrics, 11(6), 619-632. 
Rich, T. S. (2009). Status for sale: Taiwan and the competition for diplomatic recognition. Issues \& Studies, 45(4), 159-188.

Rotberg, R. I. (Ed.). (2009). China into Africa: Trade, aid, and influence. Brookings Institution Press.

Saidi, M. D., \& Wolf, C. (2011). Recalibrating Development Co-operation.

Sanfilippo, M. (2010). Chinese FDI to Africa: what is the nexus with foreign economic cooperation?. African Development Review, 22(s1), 599-614.

Shambaugh, D. (2015). China's Soft-Power Push. Foreign Aff., 94, 99.

Shepherd, B. (2010). Geographical diversification of developing country exports. World development, 38(9), 1217-1228.

Silva, J. S., \& Tenreyro, S. (2006). The log of gravity. The Review of Economics and statistics, 88(4), 641658.

Silva, J. S., \& Tenreyro, S. (2011). Further simulation evidence on the performance of the Poisson pseudo-maximum likelihood estimator. Economics Letters, 112(2), 220-222.

StataCorp. (2015). Stata 14 Base Reference Manual. College Station, TX: Stata Press.

Strange, A., Cheng, M., Russell, B., Ghose, S., \& Parks, B. (2017). AidData's Tracking Underreported Financial Flows (TUFF) Methodology, Version 1.3. Williamsburg, VA: AidData.

Strezhnev, A., \& Voeten, A. (2013). United Nations General Assembly voting data. 2013. URL http://hdl. handle. net/1902.1/12379.

Stubbs, T. H., Kentikelenis, A. E., \& King, L. P. (2016). Catalyzing aid? The IMF and donor behavior in aid allocation. World Development, 78, 511-528.

Wang, H. (2016). A deeper look at China's "going out" policy, Commentary, March, Center for International Governance Innovation; https://www.cigionline.org/publications/deeper-look-chinasgoing-out-policy.

Woods, N. (2008). Whose aid? Whose influence? China, emerging donors and the silent revolution in development assistance. International Affairs, 84(6), 1205-1221.

Xue, L. (2014). China's foreign aid policy and architecture. IDS Bulletin, 45(4), 36-45.

You, K., \& Solomon, O. H. (2015). China's outward foreign direct investment and domestic investment: An industrial level analysis. China Economic Review, 34, 249-260.

Younas, J. (2008). Motivation for bilateral aid allocation: Altruism or trade benefits. European Journal of Political Economy, 24(3), 661-674.

Zhang, D., \& Smith, G. (2017). China's foreign aid system: structure, agencies, and identities. Third World Quarterly, 38(10), 2330-2346. 
Appendix A: Herfindahl-Hirschman concentration indexes for projects and amount by sector

\begin{tabular}{|c|c|c|c|c|c|}
\hline \multicolumn{5}{|c|}{ Herfindahl-Hirschman concentration indexes } \\
\hline \multicolumn{2}{|c|}{ Social sector } & \multicolumn{2}{c|}{ Economic sector } & \multicolumn{2}{c|}{ Production sector } \\
\hline Projects & Amount & Projects & Amount & Projects & Amount \\
\hline 0.0321 & 0.1617 & 0.0749 & 0.1277 & 0.0722 & 0.4767 \\
\hline
\end{tabular}

Table A1: Herfindahl-Hirschman concentration indexes for projects and amount 


\section{Appendix B: Description of variables used in the regression analyses}

\begin{tabular}{|c|c|c|}
\hline Variable name & Definition & Source \\
\hline Total projects & $\begin{array}{l}\text { Number of Chinese ODA projects in the social, economic } \\
\text { and production sectors }\end{array}$ & AidData's Dataset \\
\hline Social projects & Number of Chinese ODA projects in the social sector & AidData's Dataset \\
\hline $\begin{array}{l}\text { Economic } \\
\text { projects }\end{array}$ & Number of Chinese ODA projects in the economic sector & AidData's Dataset \\
\hline $\begin{array}{l}\text { Economic } \\
\text { amount }\end{array}$ & $\begin{array}{l}\text { Amount of Chinese ODA in the economic sector (2014 } \\
\text { US\$) }\end{array}$ & AidData's Dataset \\
\hline $\begin{array}{l}\text { Production } \\
\text { projects }\end{array}$ & $\begin{array}{c}\text { Number of Chinese ODA projects in the production } \\
\text { sector }\end{array}$ & AidData's Dataset \\
\hline GDP per capita & Logged GDP per capita (2011 US\$), lag & World Bank data \\
\hline Debt to GNI ratio & $\begin{array}{l}\text { Total debt service (sum of principal repayments and } \\
\text { interest actually paid in currency, goods, or services on } \\
\text { long-term debt, interest paid on short-term debt, and } \\
\text { repayments to the IMF) in \% of GNI, lag }\end{array}$ & World Bank data \\
\hline Population & Logged population, lag & World Bank data \\
\hline $\begin{array}{l}\text { Control of } \\
\text { corruption index }\end{array}$ & $\begin{array}{c}\text { Index representing the control of corruption ranging } \\
\text { from }-2.5 \text { to } 2.5 \text { with higher values corresponding to } \\
\text { better governance, lag }\end{array}$ & $\begin{array}{l}\text { World Bank data from the } \\
\text { Worldwide Governance Indicators } \\
\text { (Kaufmann et al., 2011); } \\
\text { https://data.worldbank.org/ }\end{array}$ \\
\hline $\begin{array}{l}\text { Natural } \\
\text { resources rent }\end{array}$ & $\begin{array}{c}\text { The total natural resources rent, is the sum of oil, natural } \\
\text { gas, coal (hard and soft), mineral and forest rents, } \\
\text { expressed in \% of GDP, lag }\end{array}$ & $\begin{array}{c}\text { World Bank data ; } \\
\text { https://data.worldbank.org/ }\end{array}$ \\
\hline Openness rate & $\begin{array}{l}\text { Exports of China to recipient countries plus exports of } \\
\text { recipient countries to China, expressed as \% of African } \\
\text { countries' GDP, lag }\end{array}$ & $\begin{array}{l}\text { World Integrated Trade Solution ; } \\
\text { https://wits.worldbank.org/ }\end{array}$ \\
\hline $\begin{array}{l}\text { UNGA voting } \\
\text { alignment }\end{array}$ & $\begin{array}{c}\text { Voting alignment in the United Nations General } \\
\text { Assembly with China in all vote, expressed in \%, lag }\end{array}$ & Strezhnev and Voeten (2013) \\
\hline $\begin{array}{l}\text { Taiwan } \\
\text { recognition }\end{array}$ & $\begin{array}{c}\text { Equal to } 1 \text { if the country has diplomatic relations with } \\
\text { Taiwan and } 0 \text { otherwise, lag }\end{array}$ & Rich (2009), own calculation \\
\hline $\begin{array}{l}\text { English-speaking } \\
\text { country }\end{array}$ & $\begin{array}{l}\text { Equal to } 1 \text { if English is an official language in the country } \\
\text { and } 0 \text { otherwise }\end{array}$ & Own calculation \\
\hline $\begin{array}{l}\text { Total ODA DAC } \\
\text { countries }\end{array}$ & $\begin{array}{l}\text { ODA commitments of DAC countries in the social, } \\
\text { economic and production sectors, } 2015 \text { US\$ million }\end{array}$ & $\begin{array}{c}\text { OECD ; http://www.oecd- } \\
\text { ilibrary.org/development/data/detai } \\
\text { led-aid-statistics_dev-aid-stat-data- } \\
\text { en }\end{array}$ \\
\hline $\begin{array}{l}\text { Social ODA DAC } \\
\text { countries }\end{array}$ & $\begin{array}{l}\text { ODA commitments of DAC countries in the social sector, } \\
\qquad 2015 \text { US\$ million }\end{array}$ & $\begin{array}{l}\text { OECD; http://www.oecd- } \\
\text { ilibrary.org/development/data/detai } \\
\text { led-aid-statistics_dev-aid-stat-data- } \\
\text { en }\end{array}$ \\
\hline $\begin{array}{l}\text { Economic ODA } \\
\text { DAC countries }\end{array}$ & $\begin{array}{l}\text { ODA commitments of DAC countries in the economic } \\
\text { sector, } 2015 \text { US\$ million }\end{array}$ & $\begin{array}{c}\text { OECD ; http://www.oecd- } \\
\text { ilibrary.org/development/data/detai } \\
\text { led-aid-statistics_dev-aid-stat-data- } \\
\text { en }\end{array}$ \\
\hline $\begin{array}{l}\text { Production ODA } \\
\text { DAC countries }\end{array}$ & $\begin{array}{l}\text { ODA commitments of DAC countries in the production } \\
\text { sector, } 2015 \text { US\$ million }\end{array}$ & $\begin{array}{c}\text { OECD; http://www.oecd- } \\
\text { ilibrary.org/development/data/detai } \\
\text { led-aid-statistics_dev-aid-stat-data- } \\
\text { en }\end{array}$ \\
\hline HDI & Human development Index, lag & $\begin{array}{c}\text { World Bank data ; } \\
\text { https://data.worldbank.org/ }\end{array}$ \\
\hline
\end{tabular}


Corruption

perceptions

Index
The corruption perceptions index ranks countries based on how corrupt a country's public sector is perceived to be. It ranges between 0 (highly corrupt) and 10 (very clean), lag
Transparency International ; https://www.transparency.org/rese arch/cpi/overview

The regulatory quality index rates the ability of the government to formulate and implement sound policies

Rule of law Index and regulations that permit and promote private sector development. It is measured on a scale from -2.5 to 2.5 where the score of 2.5 represents the best political governance, lag

The rule of law index measures the extent to which

Voice and accountability Index agents have confidence in and abide by the rules of society. It is measured on a scale from -2.5 to 2.5 where the score of 2.5 represents the best political governance, rights, the police, and the courts), lag
World Bank data from the Worldwide Governance Indicators

(Kaufmann et al., 2011) ; https://data.worldbank.org/

World Bank data from the Worldwide Governance Indicators

(Kaufmann et al., 2011) ; https://data.worldbank.org/

Table B1: Definition and source of variables used in regression analyses 
Appendix C: Results of regression analysis using alternative measures of needs and merits 


\begin{tabular}{|c|c|c|c|c|c|c|c|c|}
\hline & \multirow[b]{2}{*}{$\begin{array}{l}\text { Total } \\
\text { projects }\end{array}$} & \multirow[b]{2}{*}{$\begin{array}{l}\text { Social } \\
\text { projects }\end{array}$} & \multirow[b]{2}{*}{$\begin{array}{l}\text { Economic } \\
\text { projects }\end{array}$} & \multirow[b]{2}{*}{$\begin{array}{c}\text { Economic } \\
\text { amount }\end{array}$} & \multirow[b]{2}{*}{$\begin{array}{l}\text { Production } \\
\text { projects }\end{array}$} & \multicolumn{3}{|c|}{$\begin{array}{l}\text { Chi-squared test for equality of coefficients (ODA } \\
\text { projects) }\end{array}$} \\
\hline & & & & & & $\begin{array}{c}\text { Social versus } \\
\text { economic }\end{array}$ & $\begin{array}{c}\text { Social versus } \\
\text { production }\end{array}$ & $\begin{array}{c}\text { Economic versus } \\
\text { production }\end{array}$ \\
\hline Human development index & $\begin{array}{l}0.199 * * \\
(0.134) \\
\end{array}$ & $\begin{array}{l}0.191^{* *} \\
(0.136) \\
\end{array}$ & $\begin{array}{c}1.011 \\
(1.217) \\
\end{array}$ & $\begin{array}{c}0.376 \\
(1.021) \\
\end{array}$ & $\begin{array}{c}0.0297^{* * *} \\
(0.0390)\end{array}$ & 1.95 & 2.26 & $3.86^{* *}$ \\
\hline Debt to GNI ratio & $\begin{array}{c}0.995^{* *} \\
(0.00222) \\
\end{array}$ & $\begin{array}{l}0.993 * * * \\
(0.00254) \\
\end{array}$ & $\begin{array}{c}0.998 \\
(0.00412) \\
\end{array}$ & $\begin{array}{c}0.993 \\
(0.0163) \\
\end{array}$ & $\begin{array}{c}1.000 \\
(0.00280) \\
\end{array}$ & 2.63 & $3.34^{*}$ & 0.17 \\
\hline Population (log) & $\begin{array}{l}0.904^{* *} \\
(0.0448)\end{array}$ & $\begin{array}{c}0.913^{*} \\
(0.0459)\end{array}$ & $\begin{array}{c}0.866^{*} \\
(0.0702)\end{array}$ & $\begin{array}{c}1.059 \\
(0.138)\end{array}$ & $\begin{array}{c}0.952 \\
(0.0867) \\
\end{array}$ & 0.45 & 0.22 & 0.55 \\
\hline Control of corruption index & $\begin{array}{l}0.769 * * \\
(0.0962)\end{array}$ & $\begin{array}{c}0.893 \\
(0.129)\end{array}$ & $\begin{array}{l}0.496 * * * \\
(0.0860)\end{array}$ & $\begin{array}{c}0.681 \\
(0.272)\end{array}$ & $\begin{array}{c}0.530^{* * *} \\
(0.110)\end{array}$ & $7.81^{* * *}$ & $6.63^{* * *}$ & 0.06 \\
\hline Natural resources rent & $\begin{array}{c}1.007 \\
(0.00514) \\
\end{array}$ & $\begin{array}{c}1.008 \\
(0.00569) \\
\end{array}$ & $\begin{array}{c}1.012^{*} \\
(0.00736) \\
\end{array}$ & $\begin{array}{l}1.036 * * * \\
(0.0112) \\
\end{array}$ & $\begin{array}{c}0.996 \\
(0.0103) \\
\end{array}$ & 0.47 & 0.97 & 1.41 \\
\hline Openness rate & $\begin{array}{c}1.003 \\
(0.00247) \\
\end{array}$ & $\begin{array}{c}1.006^{* *} \\
(0.00273) \\
\end{array}$ & $\begin{array}{l}0.987 * * * \\
(0.00490) \\
\end{array}$ & $\begin{array}{l}0.910^{* *} \\
(0.0385) \\
\end{array}$ & $\begin{array}{c}1.010^{*} \\
(0.00593) \\
\end{array}$ & $15.44^{* * *}$ & 0.37 & $8.12^{* * *}$ \\
\hline UNGA voting alignment & $\begin{array}{c}1.004^{*} \\
(0.00203)\end{array}$ & $\begin{array}{c}1.004 \\
(0.00225)\end{array}$ & $\begin{array}{c}1.007 \\
(0.00429) \\
\end{array}$ & $\begin{array}{c}0.992 \\
(0.0106) \\
\end{array}$ & $\begin{array}{c}1.002 \\
(0.00502) \\
\end{array}$ & 0.50 & 0.07 & 0.42 \\
\hline Taiwan recognition & $\begin{array}{c}2.505^{* * *} \\
(0.271) \\
\end{array}$ & $\begin{array}{c}2.118^{* * *} \\
(0.242)\end{array}$ & $\begin{array}{c}5.118^{* * *} \\
(1.080)\end{array}$ & $\begin{array}{c}4.080^{* * *} \\
(2.218) \\
\end{array}$ & $\begin{array}{c}2.624^{* * *} \\
(0.685)\end{array}$ & 0.41 & $161.50 * * *$ & $103.90^{* * *}$ \\
\hline English-speaking country & $\begin{array}{c}0.0352^{* * *} \\
(0.0261)\end{array}$ & $\begin{array}{c}0.0375^{* * *} \\
(0.0271)\end{array}$ & $\begin{array}{c}0.0520^{* * *} \\
(0.0510)\end{array}$ & $\begin{array}{l}0.0956 * * \\
(0.0998)\end{array}$ & $\begin{array}{c}0.000000464^{* * *} \\
(0.000000220)\end{array}$ & $17.47^{* * *}$ & 0.63 & $3.47^{*}$ \\
\hline Total ODA DAC countries (log) & $\begin{array}{l}1.117^{* *} \\
(0.0616) \\
\end{array}$ & & & & & & & \\
\hline Social ODA DAC countries (log) & & $\begin{array}{c}1.106^{*} \\
(0.0669)\end{array}$ & & & & & & \\
\hline Economic ODA DAC countries (log) & & & $\begin{array}{c}1.076 \\
(0.0498) \\
\end{array}$ & $\begin{array}{c}1.109 \\
(0.123)\end{array}$ & & & & \\
\hline Production ODA DAC countries (log) & & & & & $\begin{array}{c}1.119^{*} \\
(0.0659)\end{array}$ & & & \\
\hline Year fixed effects & Yes & Yes & Yes & Yes & Yes & & & \\
\hline Observations & 566 & 569 & 566 & 566 & 569 & & & \\
\hline
\end{tabular}

Table C1: Regression analyses using the HDI as an alternative measure of needs 


\begin{tabular}{|c|c|c|c|c|c|c|c|c|}
\hline & \multirow[b]{2}{*}{$\begin{array}{c}\text { Total } \\
\text { projects }\end{array}$} & \multirow[b]{2}{*}{$\begin{array}{c}\text { Social } \\
\text { projects }\end{array}$} & \multirow[b]{2}{*}{$\begin{array}{l}\text { Economic } \\
\text { projects }\end{array}$} & \multirow[b]{2}{*}{$\begin{array}{l}\text { Economic } \\
\text { amount }\end{array}$} & \multirow[b]{2}{*}{$\begin{array}{l}\text { Production } \\
\text { projects }\end{array}$} & \multicolumn{3}{|c|}{$\begin{array}{l}\begin{array}{l}\text { Chi-squared test for equality of coefficients (ODA } \\
\text { projects) }\end{array} \\
\end{array}$} \\
\hline & & & & & & $\begin{array}{l}\text { Social versus } \\
\text { economic }\end{array}$ & $\begin{array}{l}\text { Social versus } \\
\text { production }\end{array}$ & $\begin{array}{l}\text { Economic versus } \\
\text { production }\end{array}$ \\
\hline GDP per capita (log) & $\begin{array}{l}0.753^{* * *} \\
(0.0593)\end{array}$ & $\begin{array}{l}0.718^{* * *} \\
(0.0618)\end{array}$ & $\begin{array}{c}0.925 \\
(0.121)\end{array}$ & $\begin{array}{c}1.002 \\
(0.258)\end{array}$ & $\begin{array}{c}0.777 \\
(0.126)\end{array}$ & $4.12 * *$ & 0.20 & 0.65 \\
\hline Debt to GNI ratio & $\begin{array}{l}0.993 * * * \\
(0.00206) \\
\end{array}$ & $\begin{array}{l}0.992 * * * \\
(0.00228) \\
\end{array}$ & $\begin{array}{c}0.996 \\
(0.00390) \\
\end{array}$ & $\begin{array}{c}0.992 \\
(0.0143) \\
\end{array}$ & $\begin{array}{c}0.997 \\
(0.00295) \\
\end{array}$ & $2.77^{*}$ & 2.23 & 0.05 \\
\hline Population (log) & $\begin{array}{l}0.906 * * \\
(0.0444)\end{array}$ & $\begin{array}{c}0.918^{*} \\
(0.0438)\end{array}$ & $\begin{array}{c}0.889 \\
(0.0706)\end{array}$ & $\begin{array}{c}1.027 \\
(0.126)\end{array}$ & $\begin{array}{c}0.938 \\
(0.0812)\end{array}$ & 0.19 & 0.06 & 0.21 \\
\hline Corruption perception index & $\begin{array}{c}0.993 \\
(0.00675)\end{array}$ & $\begin{array}{c}1.005 \\
(0.00729)\end{array}$ & $\begin{array}{l}0.969 * * * \\
(0.0113)\end{array}$ & $\begin{array}{l}0.952 * * \\
(0.0209)\end{array}$ & $\begin{array}{l}0.952^{* * *} \\
(0.0146)\end{array}$ & $9.76 * * *$ & $10.26 * * *$ & 0.79 \\
\hline Natural resources rent & $\begin{array}{c}1.010 * * \\
(0.00478)\end{array}$ & $\begin{array}{c}1.011^{* *} \\
(0.00531)\end{array}$ & $\begin{array}{c}1.014^{*} \\
(0.00836)\end{array}$ & $\begin{array}{l}1.037 * * * \\
(0.0115)\end{array}$ & $\begin{array}{c}0.996 \\
(0.00978)\end{array}$ & 0.22 & 1.56 & 1.64 \\
\hline Openness rate & $\begin{array}{c}1.000 \\
(0.00265)\end{array}$ & $\begin{array}{c}1.002 \\
(0.00307)\end{array}$ & $\begin{array}{c}0.988^{* *} \\
(0.00531)\end{array}$ & $\begin{array}{l}0.913^{* *} \\
(0.0411)\end{array}$ & $\begin{array}{c}1.010^{*} \\
(0.00602)\end{array}$ & $5.72 * *$ & 1.95 & $6.38 * *$ \\
\hline UNGA voting alignment & $\begin{array}{c}1.004^{* *} \\
(0.00201)\end{array}$ & $\begin{array}{c}1.004^{*} \\
(0.00229)\end{array}$ & $\begin{array}{c}1.004 \\
(0.00470)\end{array}$ & $\begin{array}{c}0.993 \\
(0.0110)\end{array}$ & $\begin{array}{c}1.006 \\
(0.00618)\end{array}$ & 0.00 & 0.08 & 0.04 \\
\hline Taiwan recognition & $\begin{array}{c}0.0314 * * * \\
(0.0272)\end{array}$ & $\begin{array}{c}0.0290 * * * \\
(0.0253)\end{array}$ & $\begin{array}{c}0.0616^{* * *} \\
(0.0592)\end{array}$ & $\begin{array}{l}0.112^{* *} \\
(0.115)\end{array}$ & $\begin{array}{c}0.000000137^{* * *} \\
(7.01 \mathrm{e}-08)\end{array}$ & $8.87^{* * *}$ & $130.95 * * *$ & $131.86 * * *$ \\
\hline English-speaking country & $\begin{array}{c}2.446 * * * \\
(0.267)\end{array}$ & $\begin{array}{c}2.099 * * * \\
(0.244)\end{array}$ & $\begin{array}{c}4.775^{* * *} \\
(1.047)\end{array}$ & $\begin{array}{c}4.649 * * * \\
(2.614)\end{array}$ & $\begin{array}{c}2.404^{* * *} \\
(0.607)\end{array}$ & $15.94 * * *$ & 0.27 & $3.96 * *$ \\
\hline Total ODA DAC countries (log) & $\begin{array}{c}1.115^{*} \\
(0.0661) \\
\end{array}$ & & & & & & & \\
\hline Social ODA DAC countries (log) & & $\begin{array}{c}1.099 \\
(0.0700)\end{array}$ & & & & & & \\
\hline Economic ODA DAC countries (log) & & & $\begin{array}{c}1.070 \\
(0.0503) \\
\end{array}$ & $\begin{array}{c}1.123 \\
(0.111) \\
\end{array}$ & & & & \\
\hline Production ODA DAC countries (log) & & & & & $\begin{array}{c}1.079 \\
(0.0706) \\
\end{array}$ & & & \\
\hline Year fixed effects & Yes & Yes & Yes & Yes & Yes & & & \\
\hline Observations & 523 & 524 & 523 & 523 & 524 & & & \\
\hline & & Inciden & ate ratios; & $0.10, * * p$ & $.05, * * * p<0.01$ & & & \\
\hline
\end{tabular}

Table C2: Regression analyses using the CPI as an alternative measure of merits 


\begin{tabular}{|c|c|c|c|c|c|c|c|c|}
\hline & \multirow[b]{2}{*}{$\begin{array}{c}\text { Total } \\
\text { projects }\end{array}$} & \multirow[b]{2}{*}{$\begin{array}{c}\text { Social } \\
\text { projects }\end{array}$} & \multirow[b]{2}{*}{$\begin{array}{l}\text { Economic } \\
\text { projects }\end{array}$} & \multirow[b]{2}{*}{$\begin{array}{c}\text { Economic } \\
\text { amount }\end{array}$} & \multirow[b]{2}{*}{$\begin{array}{c}\text { Production } \\
\text { projects }\end{array}$} & \multicolumn{3}{|c|}{$\begin{array}{l}\text { Chi-squared test for equality of coefficients (ODA } \\
\text { projects) }\end{array}$} \\
\hline & & & & & & $\begin{array}{c}\text { Social versus } \\
\text { economic }\end{array}$ & $\begin{array}{l}\text { Social versus } \\
\text { production }\end{array}$ & $\begin{array}{l}\text { Economic versus } \\
\text { production }\end{array}$ \\
\hline GDP per capita (log) & $\begin{array}{l}0.742 * * * \\
(0.0565)\end{array}$ & $\begin{array}{c}0.745^{* * *} \\
(0.0590)\end{array}$ & $\begin{array}{c}0.846 \\
(0.107) \\
\end{array}$ & $\begin{array}{c}0.882 \\
(0.201) \\
\end{array}$ & $\begin{array}{c}0.619 * * * \\
(0.0885) \\
\end{array}$ & 1.49 & 1.50 & $2.74^{*}$ \\
\hline Debt to GNI ratio & $\begin{array}{l}0.994 * * * \\
(0.00214) \\
\end{array}$ & $\begin{array}{l}0.992 * * * \\
(0.00232) \\
\end{array}$ & $\begin{array}{c}0.999 \\
(0.00366) \\
\end{array}$ & $\begin{array}{c}0.994 \\
(0.0157) \\
\end{array}$ & $\begin{array}{c}0.998 \\
(0.00331) \\
\end{array}$ & $6.42 * *$ & 2.16 & 0.06 \\
\hline Population (log) & $\begin{array}{l}0.912^{* *} \\
(0.0405)\end{array}$ & $\begin{array}{l}0.906 * * \\
(0.0404)\end{array}$ & $\begin{array}{c}0.936 \\
(0.0724) \\
\end{array}$ & $\begin{array}{c}1.118 \\
(0.150) \\
\end{array}$ & $\begin{array}{c}0.983 \\
(0.0932) \\
\end{array}$ & 0.18 & 0.72 & 0.15 \\
\hline Regulatory quality & $\begin{array}{c}0.903 \\
(0.0836) \\
\end{array}$ & $\begin{array}{c}0.965 \\
(0.0918) \\
\end{array}$ & $\begin{array}{c}0.699 * * * \\
(0.0911) \\
\end{array}$ & $\begin{array}{c}0.861 \\
(0.215) \\
\end{array}$ & $\begin{array}{c}0.885 \\
(0.194) \\
\end{array}$ & $6.65 * * *$ & 0.19 & 0.84 \\
\hline Natural resources rent & $\begin{array}{c}1.010 * * \\
(0.00426) \\
\end{array}$ & $\begin{array}{c}1.010 * * \\
(0.00452) \\
\end{array}$ & $\begin{array}{c}1.016 * * \\
(0.00789) \\
\end{array}$ & $\begin{array}{c}1.039 * * * \\
(0.0119) \\
\end{array}$ & $\begin{array}{c}1.003 \\
(0.0103) \\
\end{array}$ & 1.01 & 0.31 & 0.93 \\
\hline Openness rate & $\begin{array}{c}1.000 \\
(0.00246) \\
\end{array}$ & $\begin{array}{c}1.003 \\
(0.00269) \\
\end{array}$ & $\begin{array}{l}0.985^{* * *} \\
(0.00504) \\
\end{array}$ & $\begin{array}{l}0.907 * * \\
(0.0415)\end{array}$ & $\begin{array}{c}1.005 \\
(0.00618) \\
\end{array}$ & $11.84^{* * *}$ & 0.10 & $5.11 * *$ \\
\hline UNGA voting alignment & $\begin{array}{c}1.005^{* *} \\
(0.00207) \\
\end{array}$ & $\begin{array}{c}1.005^{* *} \\
(0.00230) \\
\end{array}$ & $\begin{array}{c}1.006 \\
(0.00442) \\
\end{array}$ & $\begin{array}{c}0.992 \\
(0.0116) \\
\end{array}$ & $\begin{array}{c}1.001 \\
(0.00514) \\
\end{array}$ & 0.03 & 0.60 & 0.38 \\
\hline Taiwan recognition & $\begin{array}{c}0.0382 * * * \\
(0.0274) \\
\end{array}$ & $\begin{array}{c}0.0396 * * * \\
(0.0278) \\
\end{array}$ & $\begin{array}{c}0.0623 * * * \\
(0.0593) \\
\end{array}$ & $\begin{array}{c}0.100 * * \\
(0.104) \\
\end{array}$ & $\begin{array}{c}0.000000507^{* * *} \\
(0.000000239) \\
\end{array}$ & & & \\
\hline English-speaking country & $\begin{array}{c}2.331^{* * *} \\
(0.250) \\
\end{array}$ & $\begin{array}{c}2.042 * * * \\
(0.226) \\
\end{array}$ & $\begin{array}{c}4.311^{* * *} \\
(0.856) \\
\end{array}$ & $\begin{array}{c}3.847^{* * *} \\
(1.953) \\
\end{array}$ & $\begin{array}{c}2.281^{* * *} \\
(0.641) \\
\end{array}$ & & & \\
\hline Total ODA DAC countries (log) & $\begin{array}{l}1.126^{* *} \\
(0.0677)\end{array}$ & & & & & & & \\
\hline Social ODA DAC countries (log) & & $\begin{array}{c}1.112^{*} \\
(0.0719)\end{array}$ & & & & & & \\
\hline Economic ODA DAC countries (log) & & & $\begin{array}{c}1.084 \\
(0.0575) \\
\end{array}$ & $\begin{array}{c}1.093 \\
(0.121) \\
\end{array}$ & & & & \\
\hline Production ODA DAC countries (log) & & & & & $\begin{array}{c}1.102 \\
(0.0784) \\
\end{array}$ & & & \\
\hline Year fixed effects & Yes & Yes & Yes & Yes & Yes & & & \\
\hline Observations & 578 & 581 & 578 & 578 & 581 & & & \\
\hline & & Incidenc & rate ratios; & $<0.10, * * \mathrm{p}$ & $0.05, * * * p<0.01$ & & & \\
\hline
\end{tabular}

Table C3: Regression analyses using the regulatory quality index as an alternative measure of merits 


\begin{tabular}{|c|c|c|c|c|c|c|c|c|}
\hline & \multirow[b]{2}{*}{$\begin{array}{c}\text { Total } \\
\text { projects }\end{array}$} & \multirow[b]{2}{*}{$\begin{array}{c}\text { Social } \\
\text { projects }\end{array}$} & \multirow[b]{2}{*}{$\begin{array}{l}\text { Economic } \\
\text { projects }\end{array}$} & \multirow[b]{2}{*}{$\begin{array}{c}\text { Economic } \\
\text { amount }\end{array}$} & \multirow[b]{2}{*}{$\begin{array}{c}\text { Production } \\
\text { projects }\end{array}$} & \multicolumn{3}{|c|}{$\begin{array}{l}\text { Chi-squared test for equality of coefficients (ODA } \\
\text { projects) }\end{array}$} \\
\hline & & & & & & $\begin{array}{c}\text { Social versus } \\
\text { economic }\end{array}$ & $\begin{array}{l}\text { Social versus } \\
\text { production }\end{array}$ & $\begin{array}{l}\text { Economic versus } \\
\text { production }\end{array}$ \\
\hline GDP per capita (log) & $\begin{array}{c}0.746 * * * \\
(0.0623) \\
\end{array}$ & $\begin{array}{c}0.727^{* * *} \\
(0.0625) \\
\end{array}$ & $\begin{array}{c}0.851 \\
(0.108) \\
\end{array}$ & $\begin{array}{c}0.896 \\
(0.215) \\
\end{array}$ & $\begin{array}{c}0.710^{* *} \\
(0.117) \\
\end{array}$ & 2.07 & 0.02 & 0.80 \\
\hline Debt to GNI ratio & $\begin{array}{l}0.994^{* * *} \\
(0.00189) \\
\end{array}$ & $\begin{array}{l}0.992 * * * \\
(0.00211) \\
\end{array}$ & $\begin{array}{c}0.997 \\
(0.00354) \\
\end{array}$ & $\begin{array}{c}0.994 \\
(0.0152) \\
\end{array}$ & $\begin{array}{c}0.997 \\
(0.00275) \\
\end{array}$ & $4.52 * *$ & 2.21 & 0.01 \\
\hline Population (log) & $\begin{array}{l}0.909 * * \\
(0.0423) \\
\end{array}$ & $\begin{array}{c}0.914^{*} \\
(0.0424) \\
\end{array}$ & $\begin{array}{c}0.911 \\
(0.0746) \\
\end{array}$ & $\begin{array}{c}1.094 \\
(0.148) \\
\end{array}$ & $\begin{array}{c}0.946 \\
(0.0862) \\
\end{array}$ & 0.00 & 0.14 & 0.09 \\
\hline Rule of law & $\begin{array}{c}0.917 \\
(0.120) \\
\end{array}$ & $\begin{array}{c}1.054 \\
(0.149) \\
\end{array}$ & $\begin{array}{c}0.746 \\
(0.144) \\
\end{array}$ & $\begin{array}{c}0.825 \\
(0.251) \\
\end{array}$ & $\begin{array}{c}0.594^{* * *} \\
(0.113) \\
\end{array}$ & $3.62^{*}$ & $10.63^{* * *}$ & 0.76 \\
\hline Natural resources rent & $\begin{array}{c}1.010 * * \\
(0.00454) \\
\end{array}$ & $\begin{array}{c}1.010 * * \\
(0.00479) \\
\end{array}$ & $\begin{array}{c}1.015^{*} \\
(0.00808) \\
\end{array}$ & $\begin{array}{l}1.038^{* * *} \\
(0.0114)\end{array}$ & $\begin{array}{c}0.998 \\
(0.00973) \\
\end{array}$ & 0.53 & 1.28 & 1.67 \\
\hline Openness rate & $\begin{array}{c}0.999 \\
(0.00254) \\
\end{array}$ & $\begin{array}{c}1.002 \\
(0.00275) \\
\end{array}$ & $\begin{array}{l}0.982 * * * \\
(0.00574) \\
\end{array}$ & $\begin{array}{l}0.905 * * \\
(0.0410)\end{array}$ & $\begin{array}{c}1.005 \\
(0.00580) \\
\end{array}$ & $13.70 * * *$ & 0.27 & $6.45^{* *}$ \\
\hline UNGA voting alignment & $\begin{array}{c}1.005^{* *} \\
(0.00218) \\
\end{array}$ & $\begin{array}{c}1.005^{* *} \\
(0.00248) \\
\end{array}$ & $\begin{array}{c}1.008^{*} \\
(0.00461) \\
\end{array}$ & $\begin{array}{c}0.992 \\
(0.0112) \\
\end{array}$ & $\begin{array}{c}1.002 \\
(0.00485) \\
\end{array}$ & 0.43 & 0.33 & 0.58 \\
\hline Taiwan recognition & $\begin{array}{c}0.0379 * * * \\
(0.0274) \\
\end{array}$ & $\begin{array}{c}0.0388 * * * \\
(0.0272) \\
\end{array}$ & $\begin{array}{c}0.0600 * * * \\
(0.0585) \\
\end{array}$ & $\begin{array}{c}0.102 * * \\
(0.109) \\
\end{array}$ & $\begin{array}{c}0.000000540 * * * \\
(0.000000246)\end{array}$ & 0.65 & $174.03 * * *$ & $106.50 * * *$ \\
\hline English-speaking country & $\begin{array}{c}2.380 * * * \\
(0.252) \\
\end{array}$ & $\begin{array}{c}2.044^{* * *} \\
(0.228) \\
\end{array}$ & $\begin{array}{c}.559 * * * \\
(0.919) \\
\end{array}$ & $\begin{array}{c}3.928^{* * *} \\
(2.022) \\
\end{array}$ & $\begin{array}{c}2.366^{* * *} \\
(0.642) \\
\end{array}$ & $17.63^{* * *}$ & 0.28 & $3.30^{*}$ \\
\hline Total ODA DAC countries (log) & $\begin{array}{c}1.122^{*} \\
(0.0694)\end{array}$ & & & & & & & \\
\hline Social ODA DAC countries (log) & & $\begin{array}{c}1.098 \\
(0.0700)\end{array}$ & & & & & & \\
\hline Economic ODA DAC countries (log) & & & $\begin{array}{c}1.081 \\
(0.0594) \\
\end{array}$ & $\begin{array}{c}1.101 \\
(0.122) \\
\end{array}$ & & & & \\
\hline Production ODA DAC countries (log) & & & & & $\begin{array}{l}1.158 * * \\
(0.0711)\end{array}$ & & & \\
\hline Year fixed effects & Yes & Yes & Yes & Yes & Yes & & & \\
\hline Observations & 578 & 581 & 578 & 578 & 581 & & & \\
\hline & & Incidence & te ratios; ${ }^{*}$ & $0.10, * * p<0$ & $5, * * * p<0.01$ & & & \\
\hline
\end{tabular}

Table C4: Regression analyses using the rule of law index as an alternative measure of merits 